\title{
Mechanistic Studies of In Vitro Cytotoxicity of Poly(amidoamine) Dendrimers in Mammalian Cells
}

\author{
Sourav Prasanna Mukherjee \\ sourav.mukherjee@tudublin.ie \\ Fiona Lyng \\ Technological University Dublin, fiona.lyng@tudublin.ie \\ Amaya Garcia \\ Technological University Dublin
}

See next page for additional authors

Follow this and additional works at: https://arrow.tudublin.ie/radart

Part of the Physics Commons

\section{Recommended Citation}

Mukherjee, S. et al (2010) Mechanistic Studies of In Vitro Cytotoxicity of Poly(amidoamine) Dendrimers in Mammalian Cells. Toxicology and Applied Pharmacology, Nov 1, vol.248 (3), pp.259-68. doi:10.1016/ j.taap.2010.08.016

This Article is brought to you for free and open access by the Radiation and Environmental Science Centre at ARROW@TU Dublin. It has been accepted for inclusion in Articles by an authorized administrator of ARROW@TU Dublin. For more information, please contact arrow.admin@tudublin.ie, aisling.coyne@tudublin.ie, gerard.connolly@tudublin.ie.

Funder: INSPIRE programme, funded by the Irish Government's Programme for Research in Third Level Institutions, Cycle 4, National Development Plan 20072013, supported by the European Union Structural Fund. 


\section{Authors}

Sourav Prasanna Mukherjee, Fiona Lyng, Amaya Garcia, Maria Davoren, and Hugh Byrne 
Mechanistic studies of in vitro cytotoxicity of Poly(amidoamine) dendrimers in mammalian cells

Sourav Prasanna Mukherjee*, Fiona M. Lynga , Amaya Garcia ${ }^{a}$, Maria Davoren ${ }^{\text {a }}$, Hugh J. Byrne

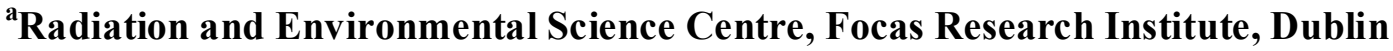
Institute of Technology, Kevin Street, Dublin 8, Ireland.

${ }^{\mathrm{b}}$ Focas Research Institute, Dublin Institute of Technology, Kevin Street, Dublin 8, Ireland.

${ }^{*}$ Corresponding Author

Sourav Prasanna Mukherjee

RESC, Focas Research Institute,

Dublin Institute of Technology

Kevin Street, Dublin 8, Ireland.

E mail address: sourav.mukherjee@dit.ie

Ph:+35314027999

Fax: +35314027901 


\section{Introduction}

Poly(amidoamine) (PAMAM) dendrimers are the first complete dendrimer family to be synthesized, characterized and commercialized (Esfand and Tomalia, 2001) and are recognized as a unique new class of synthetic nanostructures. Dendrimers allow the precise control of size, shape and placement of functional groups that is advantageous for many life science applications. Their systematically variable structural architecture and large internal free volume make these dendrimers an unique class of molecule for various biomedical applications including drug (Na et al, 2006, Yiyun et al., 2005), DNA (Guillot-Nieckowski et al., 2007, KukowskaLatallo et al., 1996), and siRNA (Zhou et al., 2006) delivery, and as MRI probes (Dear et al., 2006, Swanson et al. 2008) etc.

PAMAM dendrimers contain a 2-carbon ethylenediamine core on which the terminal amidoamines are attached yielding a highly branched radial structure having tertiary amine branches and primary amino groups on the surface. With the successive generations (G0-G10) the diameter and the number of surface amino groups systematically increase ( http://www.dendritech.com/pamam.html).

It is reported however that PAMAM dendrimers induce oxidative stress by producing reactive oxygen species (ROS) (Lee et al., 2009) and can lead to a cytotoxic response (Mukherjee et al., 2010; Naha et al., 2009). Although the response is mild, the molecular definition and the systematic variability of the size and structure of the PAMAM dendrimers render them an ideal material in which to study cytotoxic responses and elucidate their mechanisms. In both mammalian (Mukherjee et al., 2010) and ecotoxicological (Naha et al., 2009) studies, clear structure - activity relationships have been demonstrated, indicating that the toxicity increases in proportion to the surface area or number of surface groups. 
In this study, the mechanism of PAMAM toxicity is further explored in terms of generation dependant ROS production, cellular lysosomal activity, apoptosis and DNA damage. Relationships between the responses of the standard cytotoxicity assays- MTT, Alamar Blue $(\mathrm{AB})$ and Neutral Red (NR) assays are also elucidated and further framed within the context of ROS production, lysosomal activity, apoptosis and DNA damage.

\section{Materials and Methods}

\subsection{Test materials}

Polyamidoamine (PAMAM) dendrimers, G4, G5 and G6, were purchased from Sigma Aldrich Ltd. (Ireland). All the particles have an ethylenediamine core and PAMAM G4, G5 and G6 have respectively 64, 128 and 256 functional primary amino groups on the surface. The molecular weights of PAMAM G4, G5 and G6 are 14,215 Da, 28,826 Da and 58,048 Da respectively. The nominal diameters of the PAMAM G4, G5 and G6 dendrimers are 4.5, 5.4 and $6.7 \mathrm{~nm}$ respectively (http://www.dendritech.com/index.html).

\subsection{Reagents}

3-(4,5-dimethylthiazol-2-yl)-2,5-diphenyltetrazolium bromide (MTT) and Neutral Red (NR) were purchased from Sigma Aldrich Ltd. (Ireland). Alamar Blue (AB) was purchased from Biosource (UK). Cell culture media and supplements were purchased from Sigma Aldrich (Ireland) and Bioscience (Ireland). 5-(and-6)-carboxy-2',7'-dichlorofluorescein diacetate (carboxy- $\mathrm{H}_{2}$ DCFDA), LysoSensor ${ }^{\mathrm{TM}}$ Green DND-189, Lysotracker ${ }^{\circledR}$ Green DND-26 and MitoTracker $^{\circledR}$ Orange CM-H $\mathrm{H}_{2}$ TMRos was purchased from Invitrogen (Ireland). Vibrant apoptosis assay kit $\mathrm{YO}^{\mathrm{PRO}}{ }^{\circledR}-1 /$ propidium iodide was purchased from Molecular Probes ${ }^{\mathrm{TM}}$, 
Invitrogen (Ireland). APO-DIRECT ${ }^{\mathrm{TM}}$ KIT was purchased from BD Biosciences Pharmingen ${ }^{\mathrm{TM}}$ (U.K.).

\subsection{Cell Culture}

HaCaT cells, an immortal non-cancerous human keratinocyte cell line, (kindly provided by Prof. Dr. Boukamp, Heidelberg) and SW480 cells (ATCC, CCL-228), a primary adenocarcinoma cell line of the colon, were employed for testing. SW480 cells were cultured in Dulbecco's Modified Eagle's Meduim Nutrient Mixture F-12 HAM with 2mM L-glutamine supplemented with 10\% fetal bovine serum (FBS), $45 \mathrm{IU} \mathrm{ml}^{-1}$ penicillin and $45 \mathrm{IU} \mathrm{ml}^{-1}$ streptomycin at $37^{\circ} \mathrm{C}$ in $5 \% \mathrm{CO}_{2}$. HaCaT cells were cultured in the same cell culture medium under the same conditions with the addition of $1 \mu \mathrm{g} / \mathrm{ml}$ hydrocortisone.

\subsection{Preparation of Dendrimer solutions}

Dendrimer test solutions were prepared in the respective cell culture media. They were readily soluble in the media at $37^{\circ} \mathrm{C}$ and were dispersed uniformly by low speed vortex. The concentration ranges used for the cytotoxicity assays with G4, G5 and G6 were 0.01-21.1 $\mu \mathrm{M}$, 0.03-5.2 $\mu \mathrm{M}$ and 0.01-5.168 $\mu \mathrm{M}$ respectively for $\mathrm{HaCaT}$ cells and 0.01-7.03 $\mu \mathrm{M}, 0.03-5.2 \mu \mathrm{M}$ and $0.01-5.168 \mu \mathrm{M}$ respectively for SW480 cells. Concentration ranges were chosen as identified in a previous study of PAMAM dendrimer cytotoxicity (Mukherjee et al., 2010). For ROS, Lysosensor, Lysotracker and Mitotracker studies, the concentrations used for $\mathrm{HaCaT}$ cells with G4 were 1.6 - $23.2 \mu \mathrm{M}$, with G5 were $0.5-5.75 \mu \mathrm{M}$ and with G6 were 0.5 - $3.17 \mu \mathrm{M}$. For ROS in SW480 cells the concentrations used for G4 were $0.72-10.8 \mu \mathrm{M}$, for G5 were $0.18-4.33$ $\mu \mathrm{M}$, and for G6 were $0.58-1.87 \mu \mathrm{M}$. For the apoptosis study the concentrations used for HaCaT cells with G4 were $3.21-23.16 \mu \mathrm{M}$, with G5 were $1.07-5.75 \mu \mathrm{M}$, and with G6 were $1.02-3.17$ 
$\mu \mathrm{M}$. In the TUNEL assay, PAMAM G4 was used at concentrations of $3.17 \mu \mathrm{M}$ and $23.16 \mu \mathrm{M}$, G5 at a concentration of $3.17 \mu \mathrm{M}$ and $5.75 \mu \mathrm{M}$, and $\mathrm{G} 6$ at a concentration of $3.17 \mu \mathrm{M}$.

\subsection{Alamar Blue (AB) and Neutral Red (NR) assays}

$\mathrm{AB}$ and $\mathrm{NR}$ assays are standard cytotoxicity assays. The $\mathrm{AB}$ assay measures the general cellular metabolism (O'Brien et al., 2000), whereas the NR assay measures the lysosomal activity of the cell (Repetto, 2008, Yang, 2007). For the AB and NR assays, cells were seeded in 96-well microplates (Nunc, Denmark) at a density of $1 \times 10^{5}$ cells $/ \mathrm{ml}$ in $100 \mu 1$ of respective media containing 10\% FBS. After $24 \mathrm{~h}$ of cell attachment, plates were washed with $100 \mu \mathrm{l} /$ well PBS and the cells were treated with increasing concentrations of each generation of dendrimer, prepared in 5\% FBS containing media for $24 \mathrm{~h}$. All incubations were performed at $37^{\circ} \mathrm{C}$ in a $5 \%$ $\mathrm{CO}_{2}$ humidified incubator. Six replicate wells were used for each control and test concentrations per microplate.

The AB followed by the NR assays were conducted consecutively on the same set of plates. The assays were carried out according to the manufacturer's instructions. Briefly, control media or test exposures were removed; the cells were rinsed with PBS and $100 \mu 1$ of $\mathrm{AB} / \mathrm{NR}$ medium $(5 \%$ $[\mathrm{v} / \mathrm{v}]$ solution of $\mathrm{AB}$ and $1.25 \%[\mathrm{v} / \mathrm{v}]$ of NR dye) prepared in fresh media (without FBS or supplements) were added to each well. After $3 \mathrm{~h}$ incubation, $\mathrm{AB}$ fluorescence was measured at the respective excitation and emission wavelengths of $531 \mathrm{~nm}$ and $595 \mathrm{~nm}$ in a $\mathrm{VICTOR}^{3} \mathrm{~V}^{\mathrm{TM}}$ 1420 Multilabel Counter (Perkin Elmer, USA). Wells having only AB and media were used as blanks. After measurement, the wells were then washed with PBS and $100 \mu 1$ of NR fixative (50\% ethanol, $49 \% \mathrm{dH}_{2} \mathrm{O}$ and $1 \%$ glacial acetic acid) were added to each well and the plates were shaken at $240 \mathrm{rpm}$ for $10 \mathrm{~min}$. The NR fluorescence was then measured at the excitation 
and emission wavelengths of $531 \mathrm{~nm}$ and $642 \mathrm{~nm}$ respectively in the same instrument. For both assays, mean fluorescent units for the six replicate cultures were calculated for each exposure treatment.

\subsection{MTT (3-[4,5-Dimethylthiazol-2-yl]-2,5-diphenyl tetrazolium bromide) assay}

MTT assay is also a standard cytotoxicity assay and measures the mitochondrial metabolism of the cell from its mitochondrial oxidoreductase enzyme activity (Loveland et al., 1992). A parallel set of plates was set up for the MTT assay and seeded and exposed in an identical manner as described in section 2.5.1. After $24 \mathrm{~h}$ of PAMAM dendrimer exposure, the medium for the control or test exposures was removed, the cells were washed with PBS and $100 \mu$ of freshly prepared MTT in media (5 $\mathrm{mg} / \mathrm{ml}$ of MTT in media [without FBS or supplements]) were added to each well. After $3 \mathrm{~h}$ incubation, the medium was discarded and the cells were rinsed with PBS and $100 \mu 1$ of MTT fixative solution (isopropanol with $0.04 \mathrm{~N} \mathrm{HCl}$ ) were added to each well and the plates were shaken at $240 \mathrm{rpm}$ for $10 \mathrm{~min}$. The absorbance was then measured at $595 \mathrm{~nm}$ in a TECAN GENios (Grodig, Austria) plate reader.

\subsection{Lysosensor, Lysotracker \& Mitotracker study:}

The HaCaT cells were seeded at a density of $1 \times 10^{6}$ cells $/ \mathrm{ml}$ in glass bottom petri dishes for confocal fluorescence microscopic study and $1 \times 10^{5}$ cells $/ \mathrm{ml}$ in 96 well microplates for quantitative study using the plate reader, in $10 \%$ FBS supplemented media and incubated at $37^{\circ} \mathrm{C}$ in $5 \% \mathrm{CO}_{2}$ for $24 \mathrm{~h}$ for cell attachment before exposure to the dendrimers. Six concentrations of each generation of dendrimer were prepared in 5\% FBS supplemented media and the cells were exposed for $24 \mathrm{~h}$. Following the exposure period, the cells were washed twice with pre-warmed PBS $\left(37^{\circ} \mathrm{C}\right)$. The Lysosensor/Mitotracker dye solution was prepared using concentrations of 2 
$\mu \mathrm{M}$ and $250 \mathrm{nM}$ respectively in pre-warmed PBS. Cells were stained with the dye solution for 30 mins in a $37^{\circ} \mathrm{C}, 5 \% \mathrm{CO}_{2}$ incubator. Following staining, the cells were washed 3 times with prewarmed PBS to ensure complete removal of unloaded dyes. Confocal microscopic images were then taken using a Zeiss Confocal Fluorescence Microscope (LSM 510 META, Version 3.2 SP2, Carl Zeiss, Germany). For the Lysosensor assay, the excitation wavelength used was $488 \mathrm{~nm}$ and the fluorescence emission was detected using a 505-530 nm band pass filter. For the Mitotracker assay, the excitation wavelength used was $543 \mathrm{~nm}$ and the fluorescence emission was detected using a $560 \mathrm{~nm}$ long pass filter. Lysosomal activity was also quantified with Lysosensor and Lysotracker dye in a TECAN GENios (Grodig, Austria) plate reader. The Lysosensor dye used in this assay is a $\mathrm{pH}$ sensitive dye and can only quantify lysosomes of $\mathrm{pH}$ 5.2. It has recently been indicated that localisation of G5 PAMAM denrimers in lysosomes can cause an increase in $\mathrm{pH}$, however (Thomas et al, 2009). Thus Lysotracker, independent of the $\mathrm{pH}$, was employed for quantifying cellular lysosomal activity. For this study, HaCaT cells were seeded in 96 well microplates at a density of $1 \times 10^{5}$ cells $/ \mathrm{ml}$ in $100 \mu \mathrm{l}$ of respective media containing $10 \%$ FBS. Following $24 \mathrm{~h}$ cell attachment the cells were washed with pre-warmed PBS and exposed to 6 different concentrations of PAMAM of each generation. After 2, 4, 6 and $24 \mathrm{~h}$ exposures, the cells were washed twice with PBS and stained with $2 \mu \mathrm{M}$ Lysosensor and $75 \mathrm{nM}$ Lysotracker separately in PBS in two independent experiments for 30 mins in a $37^{\circ} \mathrm{C}, 5 \% \mathrm{CO}_{2}$ incubator. Then the cells were washed 3 times with pre-warmed PBS to ensure complete removal of unloaded dyes and the measurement was undertaken in the plate reader at excitation and emission wavelengths of $488 \mathrm{~nm}$ and $535 \mathrm{~nm}$ respectively.

\subsection{Intracellular Reactive Oxygen Species Study:}


Carboxy- $\mathrm{H}_{2}$ DCFDA dye was used to study the intracellular reactive oxygen species generation in HaCaT cells. The study was performed in black 96-well microplates (Nunc, Denmark), wherein the cells were seeded at a density of $1 \times 10^{5}$ cells $/ \mathrm{ml}$ in $100 \mu 1$ of respective media containing 10\% FBS. After $24 \mathrm{~h}$ of cell attachment, the cells were washed twice with $100 \mu 1 /$ well PBS and carboxy-DCFDA dye was added at a concentration of $10 \mu \mathrm{M}$ in $100 \mu 1 /$ well and the plates were kept in a $37^{\circ} \mathrm{C}, 5 \% \mathrm{CO}_{2}$ incubator for $1 \mathrm{~h}$. Following incubation, the dye solution was removed, the cells were washed twice with $100 \mu 1 /$ well PBS and were treated with 6 concentrations of each generation of dendrimer, prepared in 5\% FBS containing media. The fluorescence measurement of the oxidized DCFDA dye was measured between $1 \mathrm{~h}$ to $4 \mathrm{~h}$ and after $24 \mathrm{~h}$ exposures in HaCaT cells and between $30 \mathrm{~min}$ to $6 \mathrm{~h}$ and after $24 \mathrm{~h}$ exposures in SW480 cells at the respective excitation and emission wavelengths of $490 \mathrm{~nm}$ and $545 \mathrm{~nm}$ in a TECAN GENios (Grodig, Austria) plate reader. The HaCaT cells were also seeded at a density of $1 \times 10^{6}$ cells $/ \mathrm{ml}$, in glass bottom petri dishes for confocal fluorescence microscopic study. After $24 \mathrm{~h}$ of cell attachment, the cells were washed twice with PBS and carboxy-DCFDA dye was added at a concentration of $10 \mu \mathrm{M}$ and the Petri dishes were kept in a $37^{\circ} \mathrm{C}, 5 \% \mathrm{CO}_{2}$ incubator for $1 \mathrm{~h}$. Following incubation, the dye solution was removed, the cells were washed twice with PBS and were treated with $1 \mu \mathrm{M}$ concentrations of G6 dendrimer, prepared in 5\% FBS containing media. Following $1 \mathrm{~h}$ and $24 \mathrm{~h}$ exposures, the cells were washed twice with prewarmed PBS $\left(37^{\circ} \mathrm{C}\right)$. The Mitotracker dye solution was prepared at a concentration of $250 \mathrm{nM}$ in pre-warmed PBS. Cells were stained with the dye solution for 30 mins in a $37^{\circ} \mathrm{C}, 5 \% \mathrm{CO}_{2}$ incubator. Following staining, the cells were washed 3 times with pre-warmed PBS to ensure complete removal of unloaded dyes. Confocal microscopic images were then taken immediately 
using a Zeiss Confocal Fluorescence Microscope (LSM 510 META, Version 3.2 SP2, Carl Zeiss, Germany).

\subsection{Apoptosis study:}

This study was performed using a Partec Flow Cytometer (Partec UK Limited, U.K.). The HaCaT cells were seeded in 6 well plates at a density of $1 \times 10^{5}$ cells $/ \mathrm{ml}$ in $10 \%$ FBS media and incubated in a $5 \% \mathrm{CO}_{2}$ incubator at $37^{\circ} \mathrm{C}$ for $24 \mathrm{~h}$ for cell attachment. The cells were then exposed to 3 concentrations of dendrimers for $24 \mathrm{~h}$. Following exposure, the cells were washed twice with pre-warmed PBS and were collected by trypsinization, whereafter the trypsin was removed by centrifugation. The cells were then washed twice with pre-warmed PBS and stained with the YO-PRO-1/Propidium iodide dyes where $1 \mu 1$ of each dye was used to stain $1 \times 10^{6}$ cell $/ \mathrm{ml}$. The cells were then incubated on ice for $30 \mathrm{~min}$ and then analysed in the flow cytometer within $1.5 \mathrm{~h}$.

\subsection{TUNEL assay (Terminal dUTP Nick-End Labelling assay):}

For the TUNEL assay, HaCaT cells were seeded in T25 flasks at a density of $1 \times 10^{6}$ cells $/ \mathrm{ml}$, and following $24 \mathrm{~h}$ dendrimer exposure, were washed twice with PBS and collected in respective vials by trypsinization. The cells were then fixed with $4 \%$ paraformaldehyde in PBS (pH 7.4) and stored in $70 \%$ ethanol at $-20^{\circ} \mathrm{C}$ for $24 \mathrm{~h}$. The cells were then stained following the APODIRECT $^{\mathrm{TM}}$ KIT (BD Pharmingen ${ }^{\mathrm{TM}}$, U.K.) protocol and were analysed in the Partec Flow Cytometer (Partec UK Limited, U.K.).

\subsection{Statistics}


Fluorescence, as fluorescent units (FUs), and absorbance were all quantified using either of two microplate readers $\left(\right.$ VICTOR ${ }^{3} \mathrm{~V}^{\mathrm{TM}} 1420$ Multilabel Counter, Perkin Elmer, USA and TECAN GENios, Grodig, Austria) for the MTT, AB, NR, Lysosensor, Lysotracker and ROS assay. The apoptosis study and TUNEL assay were performed using a Partec Flow Cytometer (Partec UK Limited, U.K.) where the analyses were performed using MoFlo ${ }^{\circledR}$ and $\mathrm{CyAn}^{\mathrm{TM}}$ ADP Summit software (Version 4.3, DAKO, Denmark). The gating used for apoptosis analysis is presented in Figure 9. Experiments were conducted in at least triplicate (three independent experiments). The quantitative measurement of all the assays were expressed as mean percentage increase relative to unexposed control \pm SD. Control values were set at $0 \%$. Statistical analyses were carried out using the paired Student's t-test in Microsoft ${ }^{\circledR}$ Excel (ID Business Solutions, UK) where 95\% significance levels were accepted.

\section{Results}

\subsection{AB, NR, MTT assay:}

A generation dependent toxic response of PAMAM dendrimers, whereby the toxicity increases with increasing generation has already been reported (Table 1, reproduced from Mukherjee et al., 2010). In the $24 \mathrm{~h}$ exposure study, the MTT assay was found to be most sensitive, the NR assay the least. In general, SW480 cells were seen to exhibit a higher sensitivity to the dendrimers than the $\mathrm{HaCaT}$ cells, however, using the NR assay, at lower concentrations of all three PAMAM generations, an apparent stimulatory response was found in HaCaT cells (Figure 1) but was not as prominent in SW480 cells (Figure 2). In HaCaT cells, this apparent stimulatory response is similarly generation dependent, G6 showing the highest stimulatory response and G4 the lowest. The concentrations which elicit the response are also dependent on generation, G6 at the lowest, 
G4 the highest. A similar trend is apparent in the SW480 cells, although the standard deviation of the measurements is larger than the generation dependent variations. The results also suggest that the concentration at which the highest stimulatory response is observed for each dendrimer is directly correlated with the $\mathrm{EC}_{50}$ concentration found in the MTT assay and that the toxic/nontoxic transition concentration (or threshold concentration) found in the NR assay correlates well with the $\mathrm{EC}_{50}$ concentration found in $\mathrm{AB}$ assay (Figure 3). Such a correlation is observed for all 3 dendrimer generations suggesting origin in the underlying response mechanisms and thus the toxic pathway in $\mathrm{HaCaT}$ cells was investigated further in this study.

\subsection{Lysosensor, Lysotracker \& Mitotracker study:}

The lysosomal activity and mitochondrial content was investigated using confocal fluorescence microscopy (Figure 4) and was also quantified using the plate reader (Figure 5). At concentrations below the $\mathrm{EC}_{50}$ concentrations found in the MTT assay, an increased lysosomal activity compared to unexposed negative control cells was observed in $\mathrm{HaCaT}$ cells after $24 \mathrm{~h}$ exposure to all three dendrimer generations, but notably this activity was not observed within the first $6 \mathrm{~h}$ of dendrimer exposure where the lysosomal activity was found to be lower than the control (Figure 5). The increase in lysosomal activity is also dependant on the generation of PAMAM, whereby G6 showed highest lysosomal activity and G4 the lowest. Such significant lysosomal stimulatory activity was not observed after $24 \mathrm{~h}$ exposure of PAMAM in the lysotracker assay in SW480 cells. However, a small increase was observed between $1.5 \mu \mathrm{M}$ to $1.87 \mu \mathrm{M}$ of PAMAM G6 concentration after $6 \mathrm{~h}$ exposure (data not shown). The Mitotracker study using confocal microscopy showed a decrease in mitotracker staining with increasing PAMAM concentration and followed the trend observed in the MTT assay (Figure 4). This study 
was conducted to visually counter prove the observations from MTT assay at that concentration range.

\subsection{Intracellular Reactive Oxygen Species Study:}

The ROS study suggests that, in both HaCaT and SW480 cells, ROS is produced in a biphasic way. An initial increase in ROS levels was observed during the first hours but this decreased after $\sim 4 \mathrm{~h}$ exposure in $\mathrm{HaCaT}$ cells and after $1 \mathrm{~h}$ exposure in SW480 cells. A later rise in ROS levels was observed after $24 \mathrm{~h}$ exposure in $\mathrm{HaCaT}$ cells (Figure 6.a), whereas this intracellular ROS increase was observed after $2 \mathrm{~h}$ of PAMAM exposure in SW480 cells (Figure 6.b). The time of ROS generation is also dependent on the generation of PAMAM. In HaCaT cells, the initial maximum for G6 occurs after $1 \mathrm{~h}$ exposure, while G5 and G4 exhibit maxima after $2 \mathrm{~h}$ and $3 \mathrm{~h}$ exposure respectively. After $24 \mathrm{~h}$ PAMAM exposure in HaCaT cells, the amount of late ROS formation is also generation dependant, G6 producing the largest amount of ROS and G4 the least (Figure 6.a). In SW480 cells, an initial increase is evident in the first hour of exposure which decreases at one and half hours of exposure. The amount of ROS generation was again generation dependant, whereby at times $\leq 1 \mathrm{~h}$, G6 produced the most ROS and G4 the least (Figure 6.b). For SW480 the late increase of ROS was evident from $2 \mathrm{~h}$ exposure, where G4 generated more intracellular ROS than G5 and G6 and reached its maximum levels after $4 \mathrm{~h}$ exposure, while after $24 \mathrm{~h}$ exposure the intracellular ROS falls below the control (Figure 6.b). The confocal microscopic study on HaCaT cells confirms that the majority of ROS is generated in the mitochondria, while some was found in some vesicle-like sacs (Figure 7). The maximum amount of ROS was found to be produced at or below the $\mathrm{EC}_{50}$ concentration found in the MTT assay (Figure 8). 


\subsection{Apoptosis study}

The apoptosis study of HaCaT cells exposed to G4, G5 and G6 dendrimers suggest that with increasing concentration, the percentage of healthy and early apoptotic cells decreases, whereas the late apoptotic and dead cell populations increases (Table 2). It is notable that the decay of the healthy population is monotonic from the lowest concentrations. The two dyes used in the apoptotic study are Yo-Pro ${ }^{\circledR}-1$ and Propidium iodide (PI). Yo-Pro ${ }^{\circledR}-1$ can enter apoptotic cells whereas PI cannot. Thus Yo-Pro ${ }^{\circledR}-1$ staining indicates both the apoptotic (early and late) and the dead or necrotic cells, whereas PI staining only indicates the late apoptotic and the dead or necrotic cells (manufacturer's manual http://probes.invitrogen.com/media/pis/mp13243.pdf). In the experiment, more Yo-Pro ${ }^{\circledR}-1$ staining was observed at lower concentration of dendrimers whereas with increasing dendrimer concentration PI staining gradually increased. This confirms that the cells are entering the apoptotic pathway in this concentration range before dying. For PAMAM G6, at lower concentrations, more apoptotic cells were found in comparison to G5 and G4. At the highest concentration used in this study, i.e., the $\mathrm{EC}_{50}$ concentration of each PAMAM found in the NR assay, comparing the apoptotic population with the generation of PAMAM, it was found that the healthy and early apoptotic cell population decreases with increasing generation of PAMAM (G4>G5>G6), whereas the late apoptotic and necrotic cell population increases with generation $(\mathrm{G} 4<\mathrm{G} 5<\mathrm{G} 6)$ (Table 2). The $\mathrm{EC}_{50}$ concentrations found in the NR assay for each dendrimer also decreases with increasing generation of PAMAM (G4>G5>G6). Therefore, with increasing generation of PAMAM, cells enter apoptosis at a lower dose than the previous generation. 


\subsection{TUNEL assay:}

The TUNEL assay data further demonstrates a generation dependent toxicity. At a $3.17 \mu \mathrm{M}$ PAMAM exposure of HaCaT cells, G4, G5 and G6 showed 4.69\%, 25.87\% and 89.63\% DNA breakage respectively (Figure 10.a). The percentage damage at a fixed concentration is seen to be almost linearly correlated with the number of surface amino groups per generation, and therefore with the molar concentration of amino groups (figure 10.b). It was also found that at the $\mathrm{EC}_{50}$ concentration from the NR assay, $23.16 \mu \mathrm{M}, 5.75 \mu \mathrm{M}$ and $3.17 \mu \mathrm{M}$ for G4, G5 and G6 respectively, the level of DNA breakage for PAMAM G6 remains saturated (89.63\%), whereas those for G5 have increased to $73.44 \%$ and for G4 to $9.36 \%$. (Figure $10 . b$ ).

\section{Discussion}

The results of the cytotoxicity study have been previously reported (Mukherjee et al., 2010), whereby the toxicity of the PAMAM dendrimers was found to increase with increasing dendrimer generation, and therefore number of surface amine groups, for both $\mathrm{HaCaT}$ and SW480 cells and all end points (Table 1). The SW480 cell line, however, displayed a significantly higher response to dendrimer exposure. Although a significantly different sensitivity was seen for the three assays employed (NR, AB, MTT) there appears to be a systematic relationship between the responses of the different assays (Figure 3).

Notably, a generation dependant stimulatory dose response was observed in the NR assay in $\mathrm{HaCaT}$ cells (Figure 1). With increasing generation and therefore diameter, zeta potential and number of surface amino groups of the dendrimers, the maximum stimulatory response increases in the order $\mathrm{G} 4(16 \%)<\mathrm{G} 5(17 \%)<\mathrm{G} 6(25 \%)$, although the dose of the maximum response and 
the toxic/non-toxic transition dose decreases with increasing generation (Figure 1). It was also observed that the maximum stimulatory activity found in the NR assay correlates well with the $\mathrm{EC}_{50}$ of the MTT assay, whereas the toxic/non-toxic threshold concentration found in the NR assay correlates well with the $\mathrm{EC}_{50}$ found in the $\mathrm{AB}$ assay (Figure 3) for all generations. Such a stimulatory response was not as pronounced in the response of the NR assay in SW480 cells (Figure 2). Given the systematic nature of the observed responses, a further examination may lead to a greater understanding of the underlying mechanisms.

The NR assay is commonly employed as a viability assay and is based on the uptake of neutral red dye by living cells in its lysosomes (Repetto, 2008, Yang, 2007). Reduced viability therefore results in reduced uptake of the dye. The apparent stimulatory response in the NR assay observed here is therefore an indication of the increase of intracellular lysosomes in the presence of low doses of dendrimers in HaCaT cells.

A commonly accepted paradigm for nanoparticle cytotoxicity is one of endocytosis, encapsulation in endosomes and then lysosomes, and the increased lysosomal activity observed at low doses could point towards such a mechanism. However, such a mechanism is reported primarily for anionic particles, and cationic particles have been shown to localise in mitochondria and produce a cytotoxic response via the mitochondrial injury pathway (Xia et al 2008 and 2006), generating ROS as a result (Xia et al., 2006; Lee et al., 2009).

The study of Albertazzi et al. (2000) monitored in real-time the internalisation and intracellular trafficking of PAMAM dendrimers in HeLa immortalised cervical cells using time lapse imaging and co-localisation studies. At short times $(1 \mathrm{~h})$, the fluorescently labelled particles were observed to be membrane bound, but completely internalised within $4 \mathrm{~h}$, although it was 
acknowledged that dendrimer internalization in HeLa cells seems to be slower than in other cell lines (e.g. A549, human adenocarcinomic human alveolar basal epithelial cells (Perumal et al. 2008)). Co-localization assays with endocytic structure markers revealed that both clathrinmediated endocytosis and macropinocytosis are involved in dendrimer internalization. However, reversible dendrimer-induced permeation of cell membranes as reported by Hong et al. can also be a contributing mechanism.

Kitchens et al., 2007 reported the endosomal co-localization of PAMAM G1.5-COOH at the early stages of exposure and subsequent dendrimer trafficking to secondary endosomes and lysosomes. However, whereas PAMAM G1.5-COOH showed a high degree of localisation in early stage lysosomes (58.7 \%), the $\mathrm{G} 2-\mathrm{NH}_{2}$ dendrimer showed considerably less $(37.3 \%)$, although the degree of co-localisation increased with time. Therefore, full generation cationic dendrimers behave differently than their half generation anionic counterparts. Notably, LAMP-1 was employed to co-localize dendrimers in the lysosomes, although it has been reported that LAMP proteins are not solely confined to lysosomes but can also be found in endosomes as well as at the cell surface (Gough and Fambrough, 2007). The late increase of lysosomal activity found in our study at low doses of full generation cationic PAMAM G4, G5 and G6 is consistent with the late trafficking of these higher generations of PAMAM to the lysosomes. The differentiation in trafficking mechanisms between anionic and cationic dendrimer particles is most likely increased with increasing generation and surface charge.

In the studies of Thomas et al., 2009, the results are less clear. After $1 \mathrm{hr}$ incubation, only $58 \%$ of the fluorescently labelled G5 dendrimer are co-localised with the lysotracker red dye. It should be noted that it is not clear that the transport mechanisms of dendrimers fluorescently labelled with anionic moieties (FITC in the case of Kitchens et al., 2007 or Alexafluor in the case of 
Thomas et al., 2009) are the same as their unlabelled counterparts. For example, Gajraj and Ofoli, 2000, have reported that extrinsic labelling of fluorescein-5-isothiocyanate (FITC) to bovine serum albumin (BSA) in a ratio of 2:1 changes its adsorption and diffusion properties.

In the current study, the lysosomal activity is observed to be less than control at the early stages up to $6 \mathrm{~h}$. The absence of lysosmal activity at this stage suggests that, potentially after early endosomal transport, the dendrimers are released into the cytosol where they are free to interact with intracellular membrane structures. PAMAM dendrimers of higher generations are proposed to be good DNA, siRNA transfection agents, through a mechanism of entry through the endosomal pathway and release into the cytoplasm by the proton sponge hypothesis, thereby avoiding lysosomal degradation (Guillot-Nieckowski et al., 2007; Kukowska-Latallo et al., 1996; Zhou et al., 2006). Such a proton sponge mechanism may however be concentration dependent and at low concentration, the dendrimers by enter the cytosol via other possible ways, e.g., through nano-hole formation in the cell membrane (Hong et al., 2006).

Although, early ROS are distributed throughout the cytosol, within $24 \mathrm{~h}$ they are localised in the mitochondria as shown in Figure 7. This is consistent with the observation by Lee et al, 2009, of the co-localisation of dendrimers in mitochondria of human lung cells (WI-26 VA4) after $16 \mathrm{~h}$ exposure. Subsequent mirochondrial rupture can result in the late increase in lysosomal activity and trafficking of dendrimers in these vesicles.

The results reported here are therefore consistent with a pathway of early endosomal transport of PAMAM dendrimers into the cytosol, followed by localisation in the mitochondria (Lee et al., 2009) leading to ROS production and disruption of the mitochondrial electron transduction chain, and additional $\mathrm{O}_{2}^{-}$production (Donaldson et al., 2005) resulting in oxidative stress, and apoptosis and DNA damage, as illustrated schematically in Figure 11. Indeed, the cytotoxicity 
data (Mukherjee et al., 2010) demonstrated the MTT assay to be the most sensitive assay. ROS levels generated are dependent on the dendrimer generation, as is the final toxic response.

The intracellular ROS generation study has suggested that in $\mathrm{HaCaT}$ cells, ROS is generated in a biphasic way upon PAMAM exposure. Maximum ROS was generated in the first few hours of PAMAM exposure and the time of maximum initial ROS was also generation dependant. PAMAM G6 induces maximum ROS after $1 \mathrm{~h}$ exposure, G5 after $2 \mathrm{~h}$ exposure and G4 after $3 \mathrm{~h}$ of exposure. After this period, the levels of intracellular ROS were gradually decreased, but a late ROS generation was observed after $24 \mathrm{~h}$ of exposure and the amount of ROS is again generation dependant, whereby PAMAM G6 generates the maximum and G4 the least (Figure $6)$.

In SW480 cells, this biphasic ROS generation was also observed but not as distinctly as in $\mathrm{HaCaT}$ cells (Figure 6.b). In the first hour of exposure, the intracellular ROS increased and then reduced after one and half hours of exposure. The delayed ROS production began after $2 \mathrm{~h}$ exposure and reached a maximum after $4 \mathrm{~h}$ exposure. After $24 \mathrm{~h}$ exposure, the intracellular ROS in SW480 cells was found to be below the unexposed controls. This difference in ROS generation in these two cell lines and the higher sensitivity of SW480 cells than HaCaT cells from the standard cytotoxicity assays can be linked to the significant difference in the natural antioxidant levels (e.g.,GSH) in these two cell lines (Snow et al., 2005; Nakagawa et al., 2002).

It is reported that higher constituent levels of cellular antioxidants, redox enzymes etc. help the cell to protect itself from the oxidative stress caused by an external agent, e.g., arsenic (Snow et al., 2005). The average activities of three important intracellular redox agents, glutathione (GSH), glutathione-S-transferase, and glutathione reductase are approximately three times higher in WI38 fibroblast cells than in $\mathrm{HaCaT}$ cells and therefore upon $24 \mathrm{~h}$ exposure to arsenic $\mathrm{HaCaT}$ 
cells are 50\% more susceptible to cell death than WI38 cells (Snow et al., 2005). The natural intracellular glutathione (GSH) level of $\mathrm{HaCaT}$ cells is $7300 \mathrm{nmol} / \mathrm{mg}$ protein (Snow et al., 2005) whereas that of SW480 cells is $\sim 40 \mathrm{nmol} / \mathrm{mg}$ protein (Nakagawa et al., 2002). The higher level of antioxidants in $\mathrm{HaCaT}$ cells is therefore consistent with their greater tolerance to oxidative stress and thus lower toxic response.

The cytotoxicity study shows the MTT assay to be the most sensitive assay (Mukherjee et al., 2010). This suggests that PAMAM dendrimers cause mitochondrial toxicity (Freimoser et al., 1999) leading to mitochondrial metabolic death and oxidative stress, on a time scale of 1-4 h. The $\mathrm{AB}$ assay is less sensitive, indicating that the basic cellular metabolism and proliferative capacity are affected to a lesser degree than the mitochondria (O'Brien et al, 2000). The NR assay results indicate disruption of the lysosomal membrane integrity (Harding et al., 2004) on longer timescales in both the cell lines at a relatively higher concentration of the nanoparticles.

The highest stimulatory concentration where maximum lysosomal activity was found correlates directly to the $\mathrm{EC}_{50}$ concentration found in the MTT assay, indicating that at these concentrations the mitochondrial metabolism has been dramatically affected (Figure 3). The lysotracker and lysosensor study in $\mathrm{HaCaT}$ cells showed that the increase in lysosomal activity occurs after $24 \mathrm{~h}$.

$\mathrm{HaCaT}$ cells, in the presence of ROS, increase the intracellular concentration of $\mathrm{Cu}, \mathrm{Zn}$ superoxide dismutase in the first stage of exposure to reduce ROS and then later Mn-superoxide dismutase to continue the cellular resistance (Sasaki et al., 1997; Sasaki et al, 2000). Among different ROS scavengers, the glutathione (GSH) dependant system is of great importance (Mates, 2000). The notable increase in lysosomal activity found in HaCaT cells but not in 
SW480 cells may point towards higher resistance to the toxicant over a higher dose range in HaCaT cells in comparison to SW480 cells.

With increasing generation of PAMAM dendrimer, more intracellular ROS are generated which results in damage to the mitochondrial metabolism, registered by the MTT assay. The intracellular antioxidants at this time neutralize the initial ROS generated by PAMAM to some extent, depending on the cell type and the natural antioxidant levels, and as a result the intracellular ROS levels decrease. After prolonged exposure however, this cellular defence mechanism is impaired and the subsequent rise in ROS levels results in death of the cell. As a regular cellular defensive mechanism, lysosomes then come into play to digest and neutralize the dendrimers and their effects and as a result an increase in lysosomal activity is observed at $24 \mathrm{~h}$ exposure (Figure 5). It is furthermore conceivable that the increased lysosomal activity can be an indication of mitophagy, whereby mitochondria are degraded by lysosomes to eliminate damaged organelles (Maiuri et al., 2007, Shelburne and Trump, 1973). With increasing PAMAM concentration however, the lysosomal membrane integrity is disrupted, initiating further apoptosis, DNA damage and cellular death. At low concentrations, DNA damage is approximately linearly dependent on number of surface amine groups per dendrimer and thus with molar concentration of $-\mathrm{NH}_{2}$, (Figure 10b). However, with increasing concentration, the levels per generation tend towards saturation at $\sim 90 \%$. Notably, at the EC50 value of NR, the percentage DNA damage levels are not equal, confirming that in these systems, NR is an indicator of lysosomal activity but not viability, directly.

The apparent systematic relationship between the cytotoxicity assays indicates that at a concentration when $50 \%$ of the mitochondrial metabolism $\left(\mathrm{EC}_{50}\right.$ from MTT assay) has been affected by PAMAM exposure, the lysosomal activity increases to the maximum to neutralize 
the effect, and as a result the stimulatory activity in the NR assay is maximum at that concentration. At a concentration when the basic cellular metabolism was affected by $50 \%\left(\mathrm{EC}_{50}\right.$ from $\mathrm{AB}$ assay), the lysosomal activity and therefore the cellular defence mechanism is already significantly compromised and the lysosomal activity has reduced to the levels of the control. With further increase in PAMAM concentration, the lysososmal activity is further reduced which may indicate further damage to the lysosomal membrane and its integrity leading to further increase in apoptosis rates and cellular death.

\section{Conclusions}

The toxic pathway of the cationic PAMAM dendrimers is confirmed as localisation in the mitochondria leading to ROS production and resulting in oxidative stress, apoptosis and DNA damage. Beginning with ROS production, all processes are systematically generation dependent, further illustrating the importance of such structurally controlled and defined species for the study of the underlying toxic mechanisms. The differences observed between the different cytotoxicity assays can be understood in terms of the effect of the sequence of events on the cellular mechanisms. It is suggested that the differences in the responses of the two cell lines is based on differences in intrinsic levels of anti-oxidants, the first line of defence against the toxic pathway.

\section{Acknowledgements}

This work was conducted under the framework of the INSPIRE programme, funded by the Irish Government's Programme for Research in Third Level Institutions, Cycle 4, National Development Plan 2007-2013, supported by the European Union Structural Fund. 


\section{References}

- Dear, J.W., Kobayashi, H., Brechbiel, M.W., Star, R.A. 2006. Imaging Acute Renal Failure with Polyamine Dendrimer-Based MRI Contrast Agents. Nephron Clin Pract 103, c45-c49.

- Donaldson, K., Tran, L., Jimenez, L.A., Duffin, R., Newby, D.E., Mills, N., MacNee, W., Stone, V., 2005. Combustion-derived nanoparticles: A review of their toxicology following inhalation exposure. Particle and Fibre Toxicology 21, 2-10.

- Esfand, R., Tomalia, D.A., 2001. Poly(amidoamine) (PAMAM) dendrimers: from biomimicry to drug delivery and biomedical applications. DDT $\mathbf{6}, 427-436$.

- Freimoser, F.M., Jakob, C.A., Aebi, M., Tuor, U., 1999, The MTT [3-(4,5Dimethylthiazol-2-yl)-2,5-Diphenyltetrazolium Bromide] Assay Is a Fast and Reliable Method for Colorimetric Determination of Fungal Cell Densities. Applied and Environmental Microbiology 65, 3727-3729.

- Gough, N.R., Fambrough, D.M, 1997. Different steady state subcellular distributions of the three splice variants of lysosomeassociated membrane protein LAMP-2 are determined largely by the $\mathrm{COOH}$-terminal amino acid residue. J. Cell Biol. 137, 11611169.

- Guillot-Nieckowski, M., Eisler, S., Diederich, F., 2007. Dendritic vectors for gene transfection. New J. Chem. 31, 1111-1127.

- Harding, J.M., Couturier, C., Parsons, G.J., Ross, N.W., 2004. Evaluation of the neutral red assay as a stress response indicator in cultivated mussels (Mytilus spp.) in relation to post-harvest processing activities and storage conditions. Aquaculture 231, 315-326.

- Hong, S., Leroueil, P.R., Janus, E.K., Peters, J.L., Kober, M-M., Islam, M.T., Orr, B.G., Baker, J.R., Holl, M.M.B., 2006. Interaction of Polycationic Polymers with Supported Lipid Bilayers and Cells: Nanoscale Hole Formation and Enhanced Membrane Permeability. Bioconjugate Chem. 17, 728-734.

- Kitchens, K.M., Foraker, A.B., Kolhatkar, R.B., Swaan, P.W., Ghandehari, H., 2007. Endocytosis and Interaction of Poly (Amidoamine) Dendrimers with Caco-2 Cells. Pharmaceutical Research 24, 2138-2145. 
- Kukowska-Latallo, J. F., Bielinska, A. U., Johnson, J., Spindler, R., Tomalia, D. A. , Baker, J. R. Jr., 1996. Efficient transfer of genetic material into mammalian cells using Starburst polyamidoamine dendrimers. Proc. Natl Acad. Sci. USA, 96, 4897-902

- $\quad$ Lee, J.H., Cha, K.E., Kim, M.S., Hong, H.W., Chung, D.J., Ryu, G.,, Myung, H., 2009. Nanosized polyamidoamine (PAMAM) dendrimer-induced apoptosis mediated by mitochondrial dysfunction. Toxicology Letters 190 , 202-207

- Loveland, B.E., Johns, T.G., Mackay, I.R., Vaillant, F., Wang, Z.X., Hertzog, P.J., 1992. Validation of the MTT dye assay for enumeration of cells in proliferative and antiprolifer. Biochem Int 27, 501-10.

- Mates J.M., 2000. Effects of antioxidant enzymes in the molecular control of reactive oxygen species toxicology. Toxicology 153, 83-104.

- Mukherjee, S.P., Davoren, M., Byrne, H.J., 2010. In vitro mammalian cytotoxicological study of PAMAM dendrimers -Towards quantitative structure activity relationships. Toxicol. In Vitro 24, 1169-177.

- Na, M., Yiyun, C., Tongwen, X., Yang, D., Xiaomin, W., Zhenwei, L., Zhichao, C., Guanyi, H., Yunyu, S., Longping, W., 2006. Dendrimers as potential drug carriers. Part II. Prolonged delivery of ketoprofen by in vitro and in vivo studies. European Journal of Medicinal Chemistry 41, 670-674

- Naha, P.C., Davoren, M., Casey, A., Byrne, H.J., 2009. An Ecotoxicological Study of Poly(amidoamine) Dendrimers-Toward Quantitative Structure Activity Relationships. Environ. Sci. Technol. 43, 6864-6869.

- Nakagawa Y.,, Akao Y., Morikawa H., Hirata I., Katsu K., Naoe T., Ohishi N., Yagi K., 2002. Arsenic trioxide-induced apoptosis through oxidative stress in cells of colon cancer cell lines. Life Sciences 70, 2253-2269.

- O'Brien, J.,Wilson,I.,Orton, T., Pognan, F., 2000 Investigation of the Alamar Blue (resazurin) fluorescent dye for the assessment of mammalian cell cytotoxicity. Eur. $J$. Biochem. 267, 5421-5426.

- Repetto, G., Peso, A.D., Zurita, J.L., 2008. Neutral red uptake assay for the estimation of cell viability/cytotoxicity. Nature Protocols 3, $1125-1131$.

- Sasaki H., Akamatsu H., Horio T., 1997. Effects of a Single Exposure to UVB Radiation on the Activities and Protein Levels of Copper-Zinc and Manganese Superoxide 
Dismutase in Cultured Human Keratinocytes. Photochemistry and Photobiology 65, 707713.

- Sasaki H., Akamatsu H., Horio T., 2000. Protective Role of Copper, Zinc Superoxide Dismutase Against UVB-Induced Injury of the Human Keratinocyte Cell Line HaCaT. Journal of Investigative Dermatology 114, 502-507.

- Snow E.T., Sykora P., Durham T.R., Klein C.B., 2005. Arsenic, mode of action at biologically plausible low doses: What are the implications for low dose cancer risk? Toxicology and Applied Pharmacology 207, S557 - S564.

- Swanson, S. D., Kukowska-Latallo, J. F., Patri, A. K., Chen, C., Ge, S., Cao, Z., Kotlyar, A., East, A. T., Baker, J. R., 2008. Targeted gadolinium-loaded dendrimer nanoparticles for tumor-specific magnetic resonance contrast enhancement. International journal of nanomedicine 3, 201-210.

- Thomas, T.P., Majoros, I., Kotlyar, A., Mullen, D., Holl, M.M.B., Baker, J.R., 2009. Cationic Poly(amidoamine) Dendrimer Induces Lysosomal Apoptotic Pathway at Therapeutically Relevant Concentrations. Biomacromolecules 10, 3207-3214.

- Xia, T., Kovochich, M., Brant, J., Hotze, M., Sempf, J., Oberley, T., Sioutas, C., Yeh, J.I., Wiesner, M.R., Nel, A.E., 2006. Comparison of the Abilities of Ambient and Manufactured Nanoparticles to Induce Cellular Toxicity According to an Oxidative Stress Paradigm. Nano Letters 6, 1794-1807.1794-1807

- Xia, T., Kovochich, M., Liong, M., Zink, J. I., Nel, A. E., 2008. Cationic polystyrene nanosphere toxicity depends on cell-specific endocytic and mitochondrial injury pathways. ACS Nano. 2, 85-96.

- Yang, X., Zhang, W., Yang, Y., Xiong, X., Xie, X., Tan, X., 2007. Preliminary study on neutral red uptake assay as an alternative method for eye irritation test. AATEX 14, Special Issue, 509-514.

- Yiyun, C., Tongwen, X., Rongqiang, F., 2005. Polyamidoamine dendrimers used as solubility enhancers of ketoprofen. European Journal of Medicinal Chemistry 40, 13901393. 
- Zhou, J., Wu, J., Hafdi, N., Behr, J. P., Erbacher, P., Peng, L., 2006. PAMAM dendrimers for efficient siRNA delivery and potent gene silencing. Chemical communications (Cambridge, England) 22, 2362-2364.

- Gajraj, A., Ofoli, R.Y., 2000. Effect of Extrinsic Fluorescent Labels on Diffusion and Adsorption Kinetics of Proteins at the Liquid-Liquid Interface. Langmuir 16, 8085-8094.

- Maiuri, M.C., Zalckvar, E., Adi Kimchi, A.,Kroemer,G., 2007. Self-eating and selfkilling: crosstalk between autophagy and apoptosis. Nature Reviews-Molecular Cell Biology 8, 741-752.

- Shelburne, J.D., and Trump, B.F., 1973. Studies on Cellular Autophagocytosis. American Journal of Pathology 72, 521-540. 
Figure legends:

Figure 1. Concentration dependant effect of PAMAM G4, G5 and G6 on HaCaT cells observed in NR assay.

Figure 2. Concentration dependant effect of PAMAM G4, G5 and G6 on SW480 cells observed in NR assay.

Figure 3. Correlation of $\mathrm{EC}_{50}$ concentrations from $\mathrm{MTT}$ and $\mathrm{AB}$ assay with the dose response found in NR assay upon PAMAM G4 exposure to HaCaT cells.

Figure 4. Lysosensor- Mitotracker Study on HaCaT cells after 24h exposure of PAMAM G6- a) $0 \mu \mathrm{M}$ Control, b) $0.5 \mu \mathrm{M}$ (below $\left.\mathrm{EC}_{50} \mathrm{MTT}\right)$, c) $\left.\left.1.02 \mu \mathrm{M}\left(\mathrm{EC}_{50} \mathrm{MTT}\right), \mathrm{d}\right) 1.3 \mu \mathrm{M}\left(\mathrm{EC}_{50} \mathrm{AB}\right), \mathrm{e}\right)$ $3.17 \mu \mathrm{M}\left(\mathrm{EC}_{50} \mathrm{NR}\right)$. For every quadrate photos- Top Left: only only Lysosensor staining view, Top Right: phase contrast view, Bottom Left: only Mitotracker staining view, Bottom Right: combined view of Lysosensor and Mitotracker staining. Figure $4 \mathrm{f}$ is a digital maginification of the combined view of Figure $4 \mathrm{a}$.

Figure 5. Quantitative estimation of lysosomal activity in HaCaT cells on PAMAM G6 exposure using Lysotracker green a) after 2, 4, 6, and $24 \mathrm{~h}$ exposure, b) at different concentrations after 24 h exposure.

Figure 6. Reactive Oxygen Species study after different time point exposure of $1 \mu \mathrm{M}$ PAMAM G4, G5 and G6 dendrimers- a) in HaCaT cells, b) in SW480 cells.

Figure 7. Localization of ROS in the mitochondria of HaCaT cells after $24 \mathrm{~h}$ exposure of $1 \mu \mathrm{M}$ PAMAM G6- Top Left: only Carboxy $\mathrm{H}_{2}$ DCFDA staining, Top Right: only Mitotracker staining, Bottom Left: overlay Carboxy $\mathrm{H}_{2}$ DCFDA and Mitotracker staining, Bottom Right: phase contrast image.

Figure 8. Reactive Oxygen Species study in $\mathrm{HaCaT}$ cells after 1, 2, 3, 4 and 24 h exposure of PAMAM G6 dendrimers.

Figure 9. Apoptosis study in HaCaT cells after 24 h $1.02 \mu \mathrm{M}$ PAMAM G6 exposure by flow cytometry using YO-PRO-1 and PI. The figure shows the gating used for the analysis of healthy, early apoptotic, late apoptotic and dead cell populations. 
Figure 10. DNA breakage study on HaCaT cells after 24 h PAMAM (G4, G5 and G6) exposurea) for $3.17 \mu \mathrm{M}$ exposure of each generation of PAMAM, b) correlation of DNA breakage after $24 \mathrm{~h}, 3.17 \mu \mathrm{M}$ PAMAM exposure with number of surface amino groups. c) upon exposure of $\mathrm{EC}_{50}$ from NR assay of each generation of PAMAM dendrimers $(23.16 \mu \mathrm{M}, 5.75 \mu \mathrm{M}$ and 3.17 $\mu \mathrm{M}$ for $\mathrm{G} 4$, G5 and G6 respectively),

Figure 11. Schematic representation of PAMAM cytotoxicity (Abbreviations: LP- Long Pass, BP- Band Pass). 
Figures:

Figure 1:

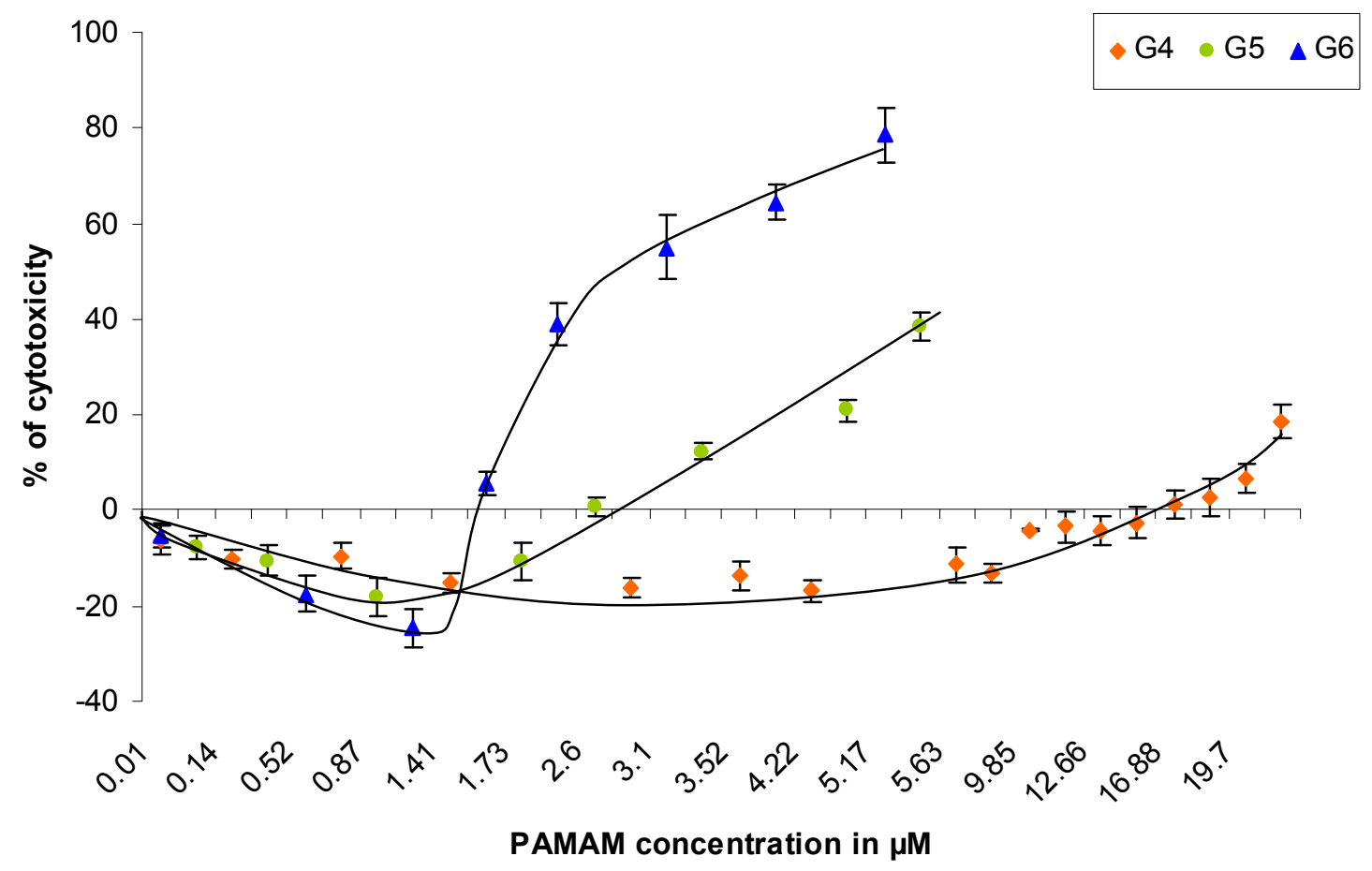


Figure 2:

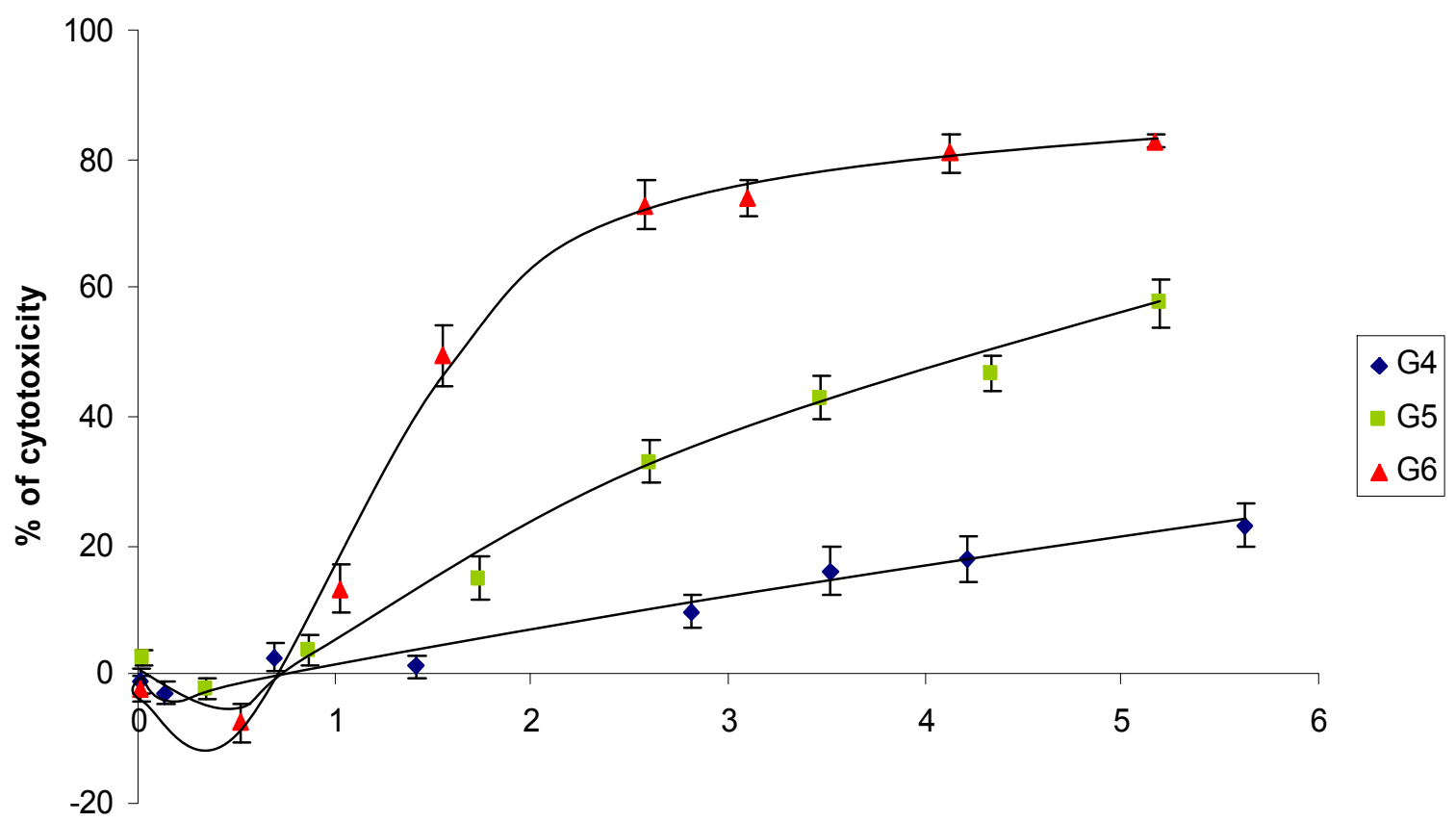

PAMAM concentration in $\mu M$ 
Figure 3:

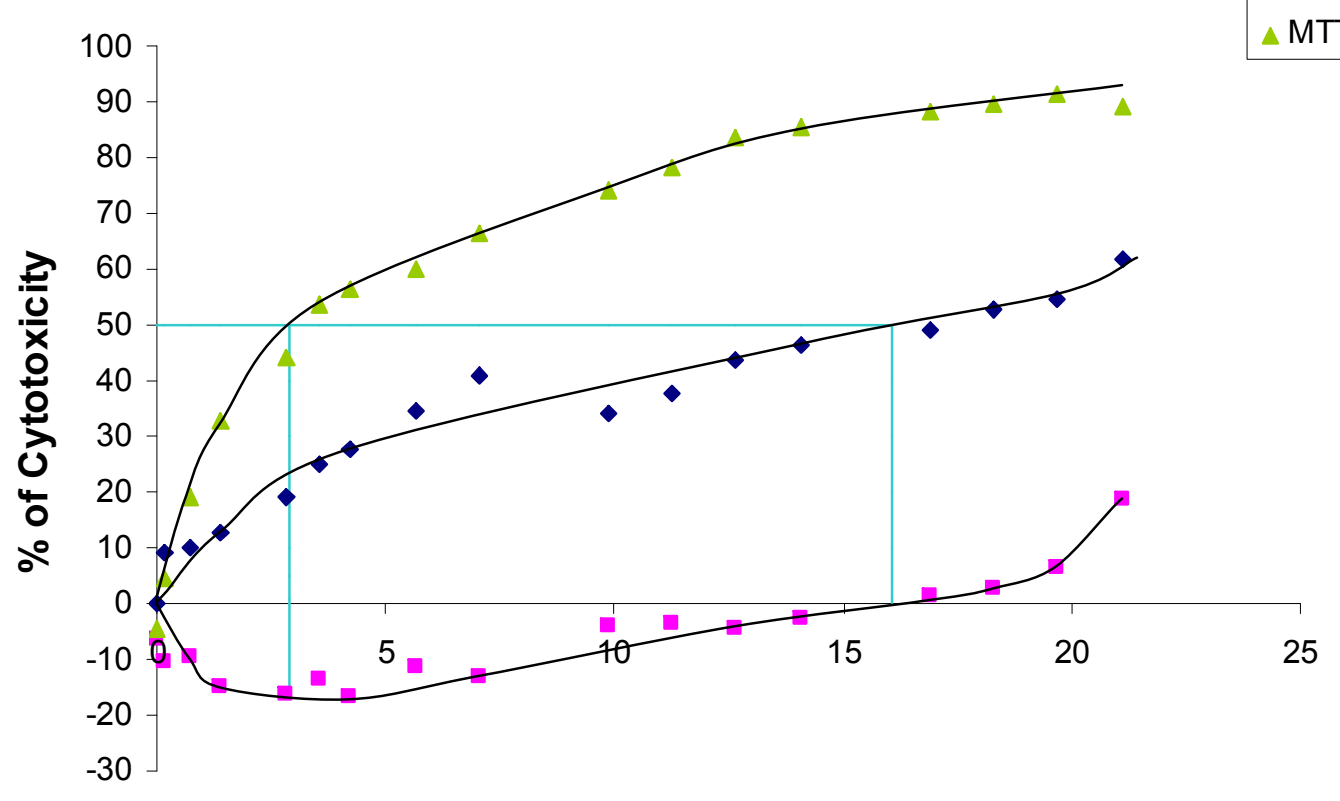

PAMAM G4 concentration ( $\mu \mathrm{M})$ 
Figure 4:

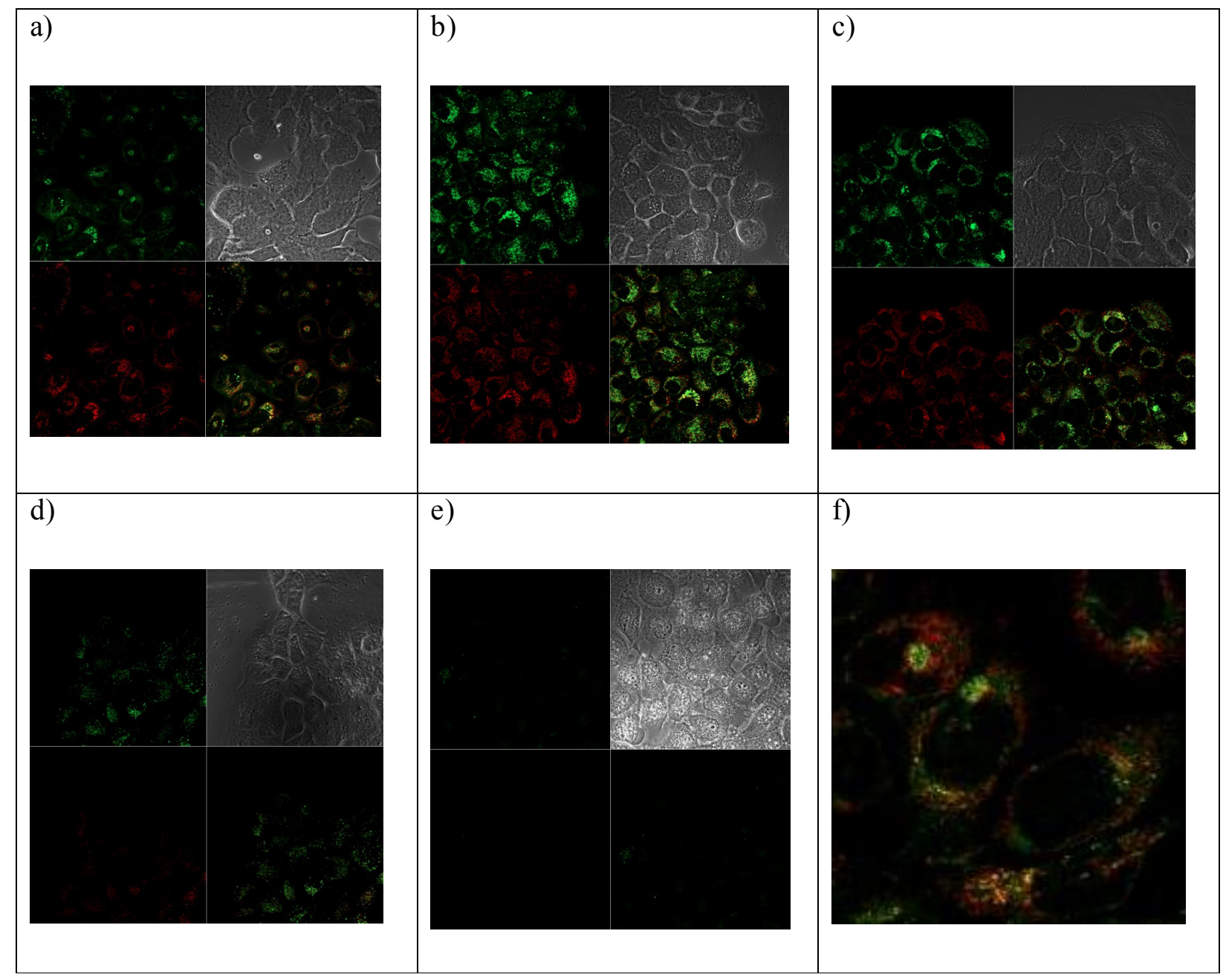


Figure 5:

a)

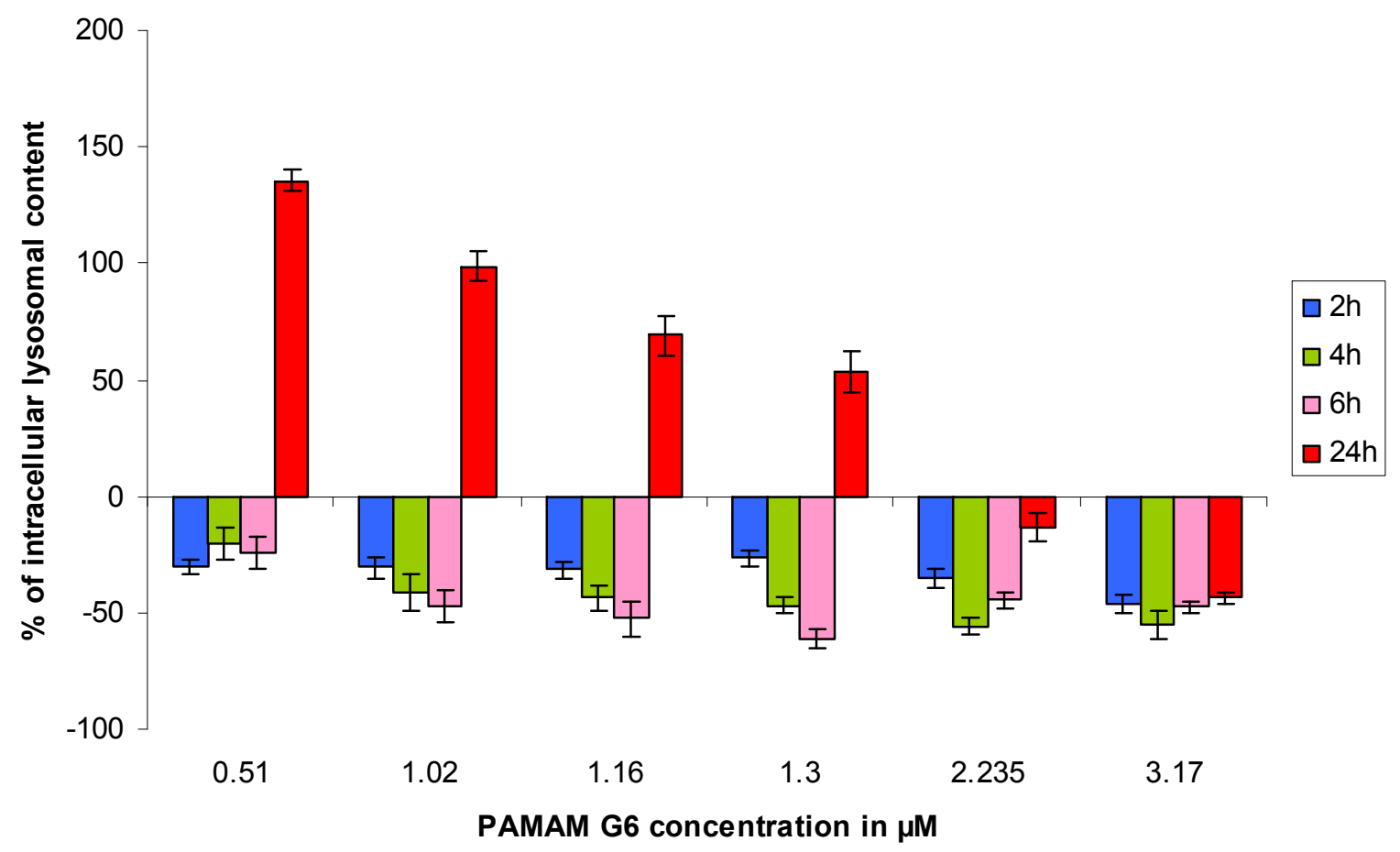


b)

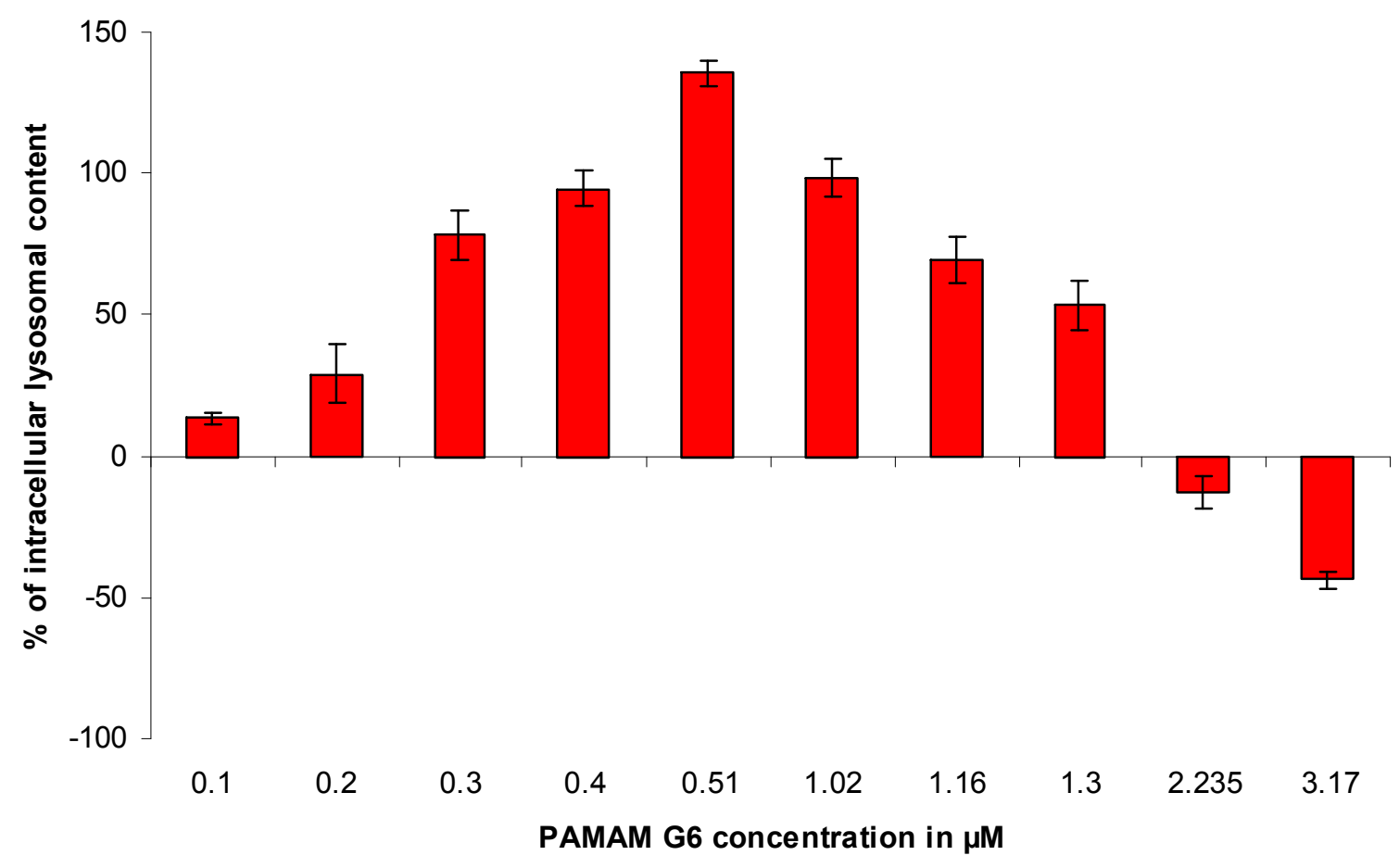


Figure 6:

a)

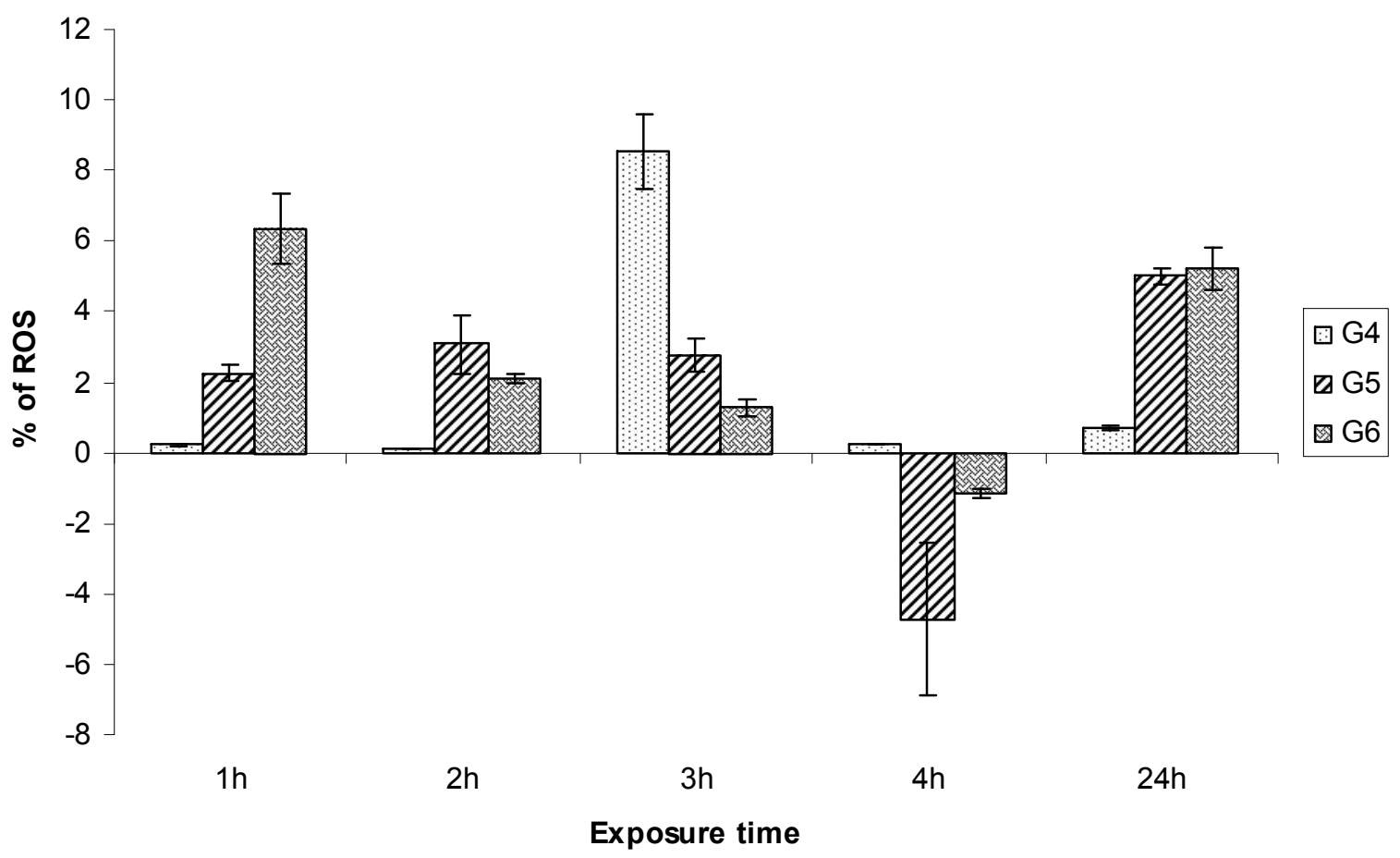


b)

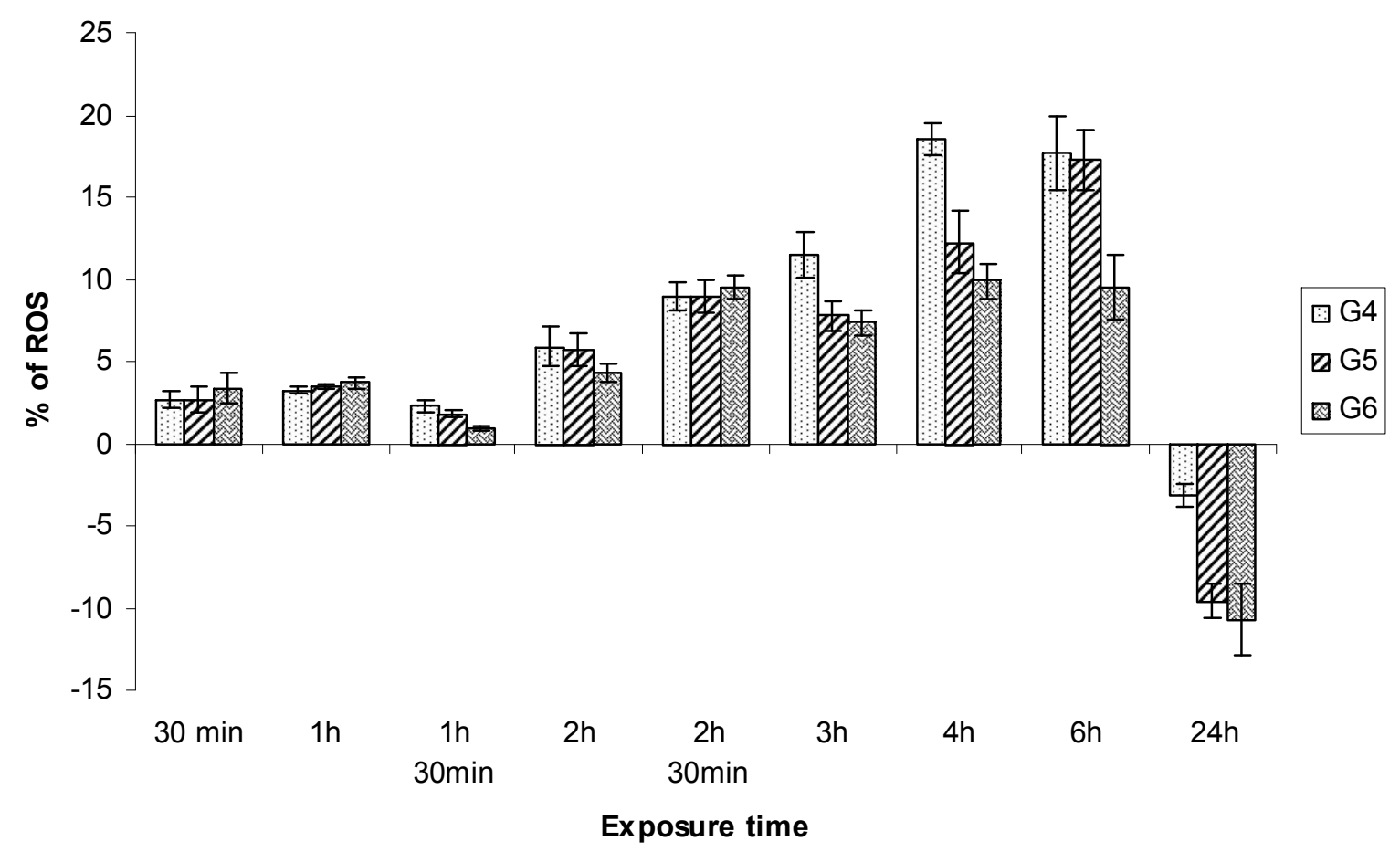


Figure 7:

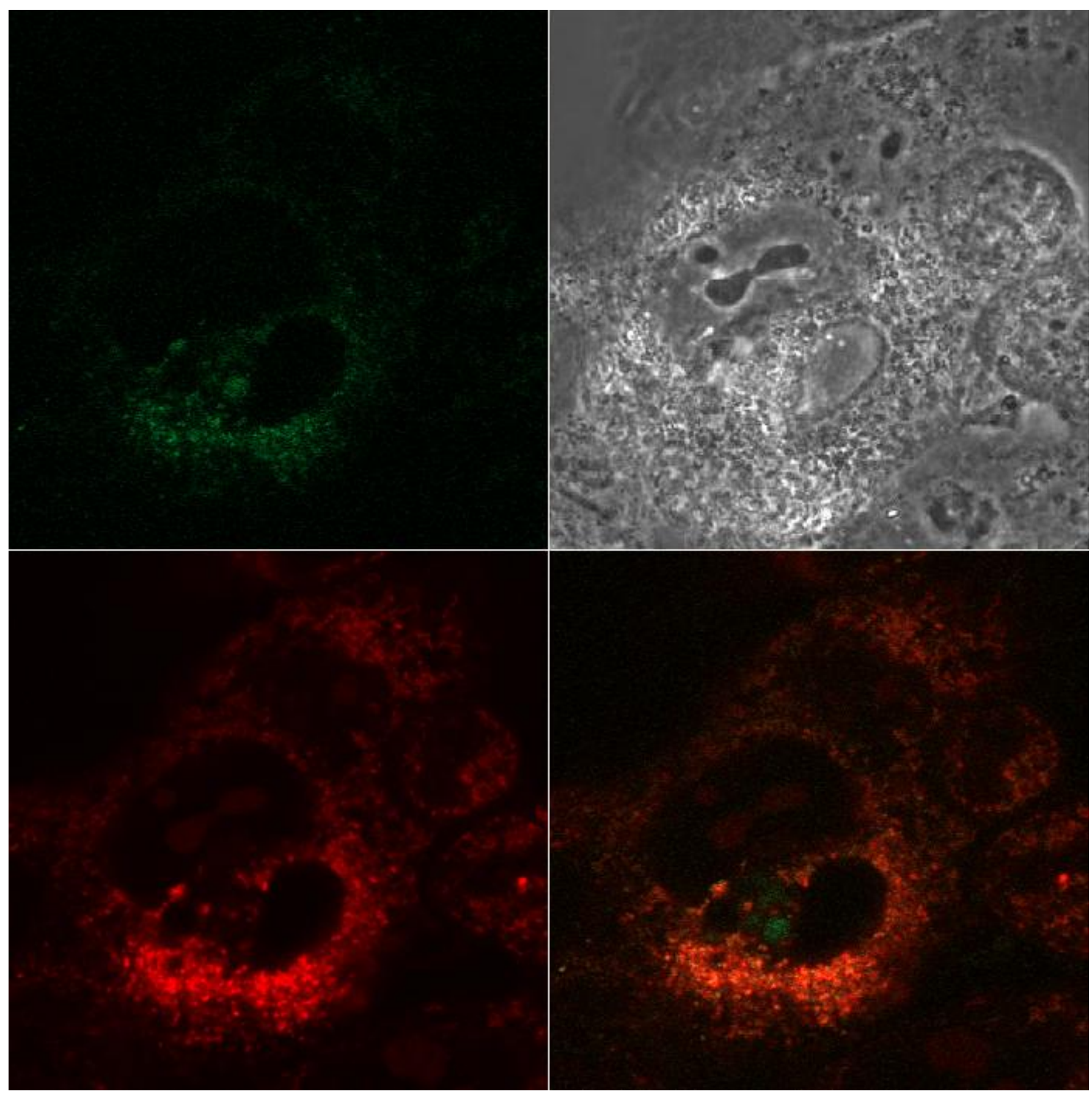


Figure 8:

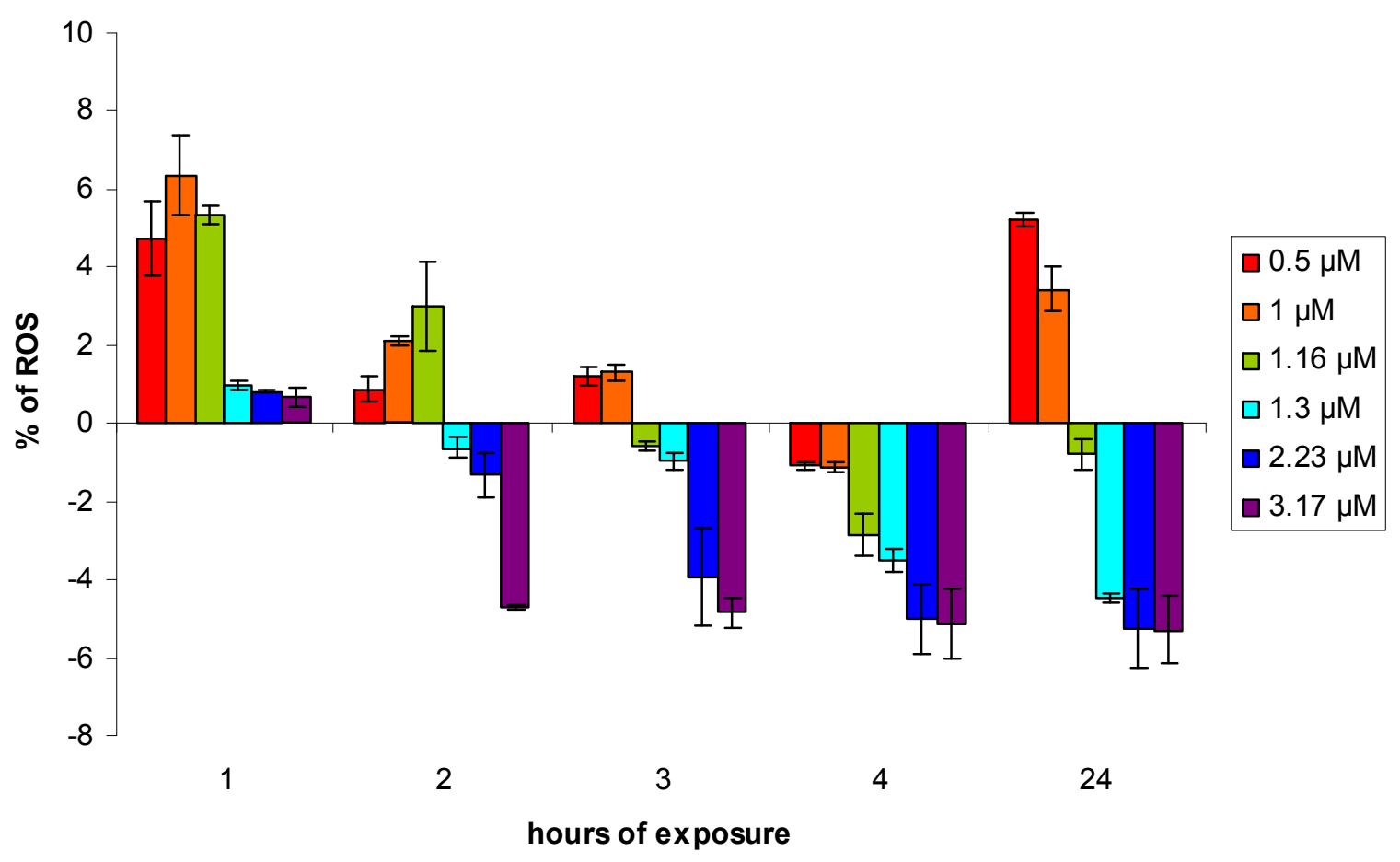


Figure 9:

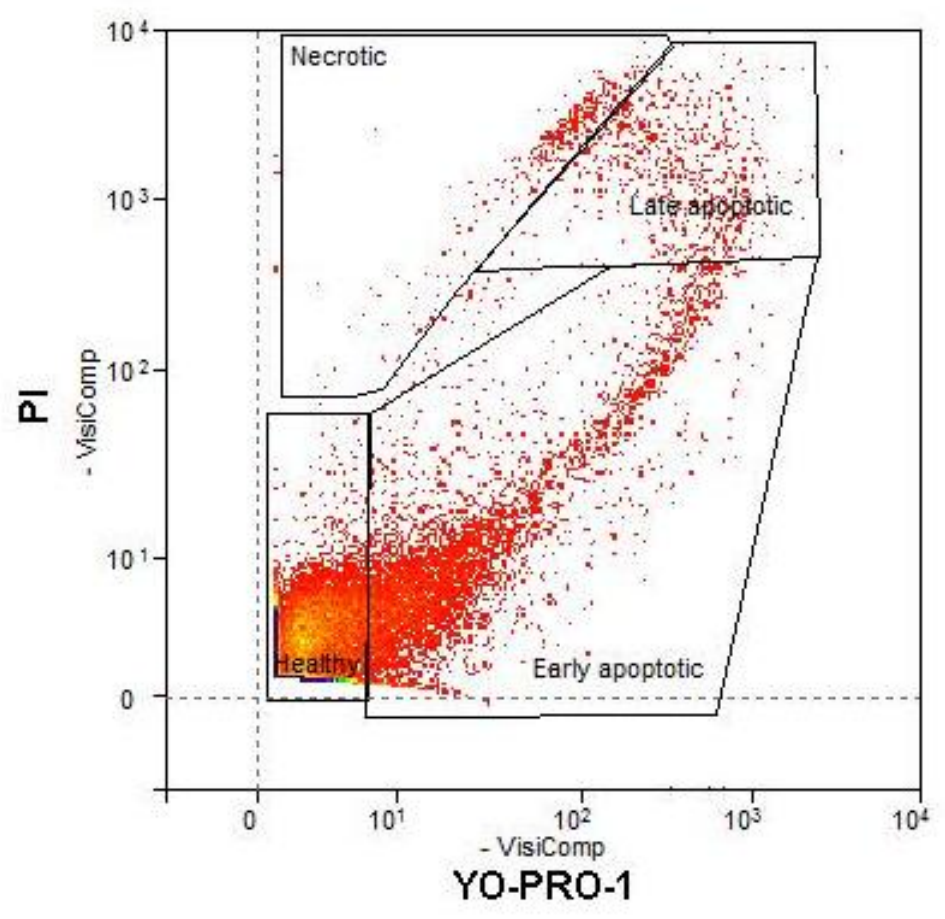


Figure 10:

a)

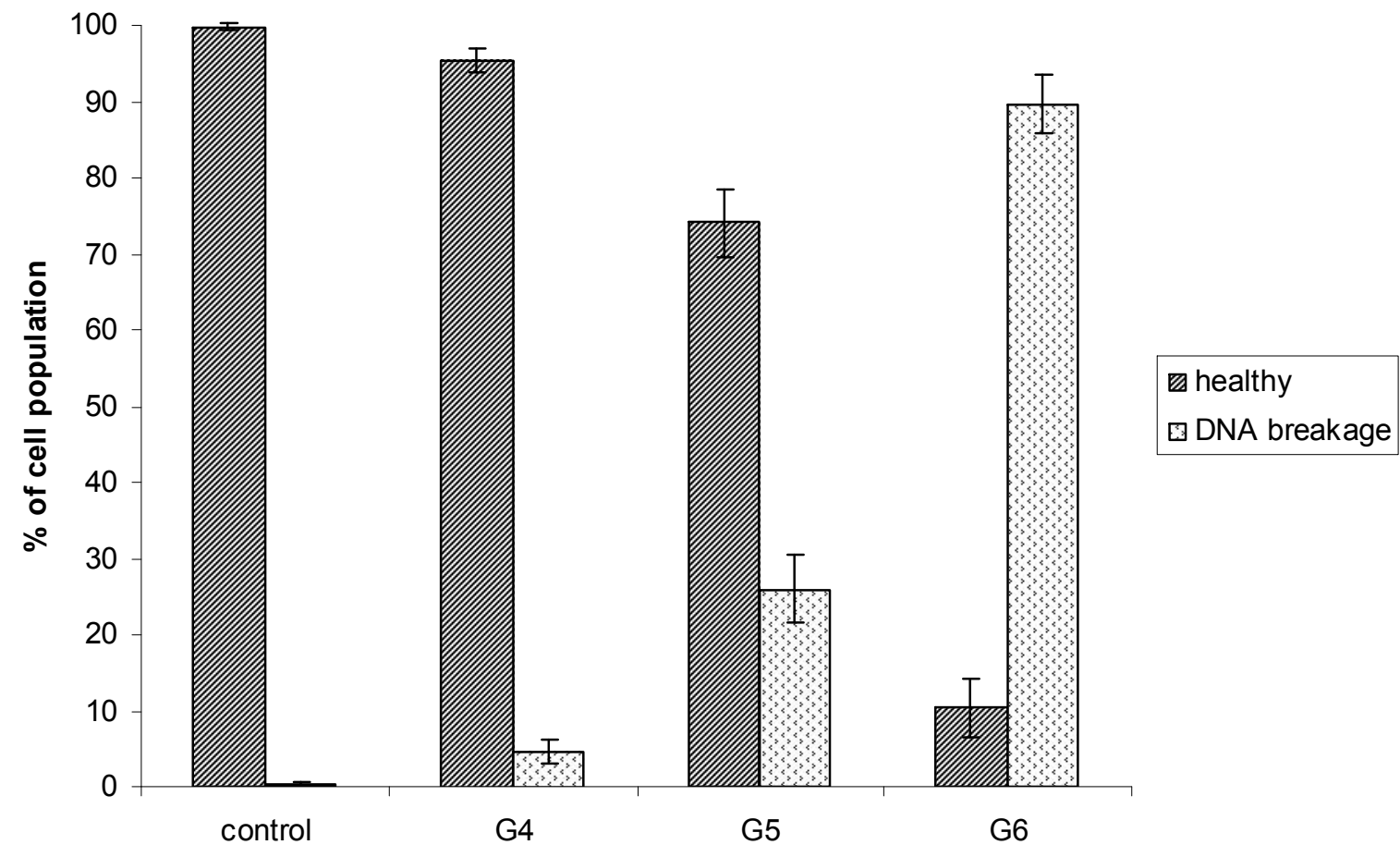


b)

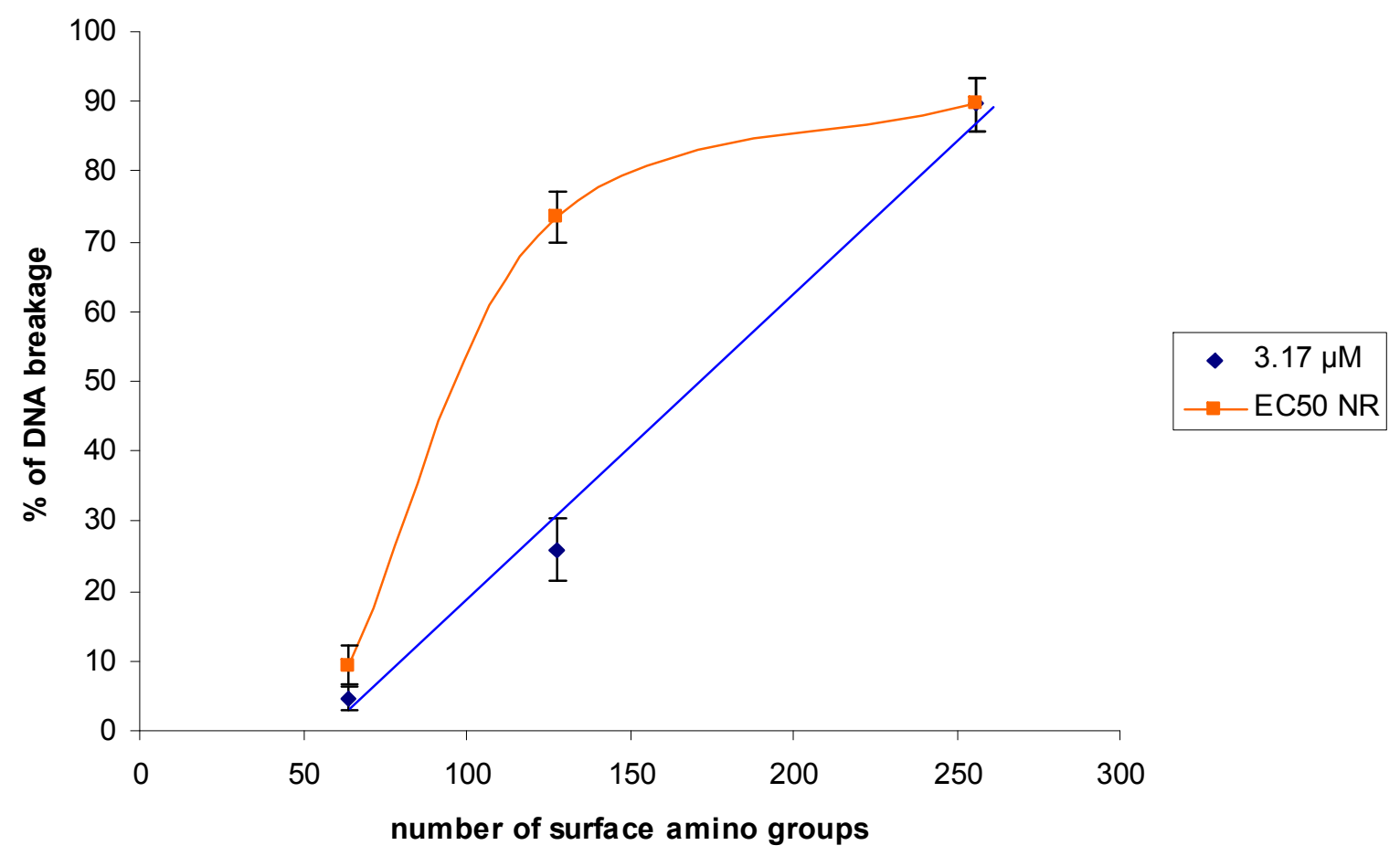


c)

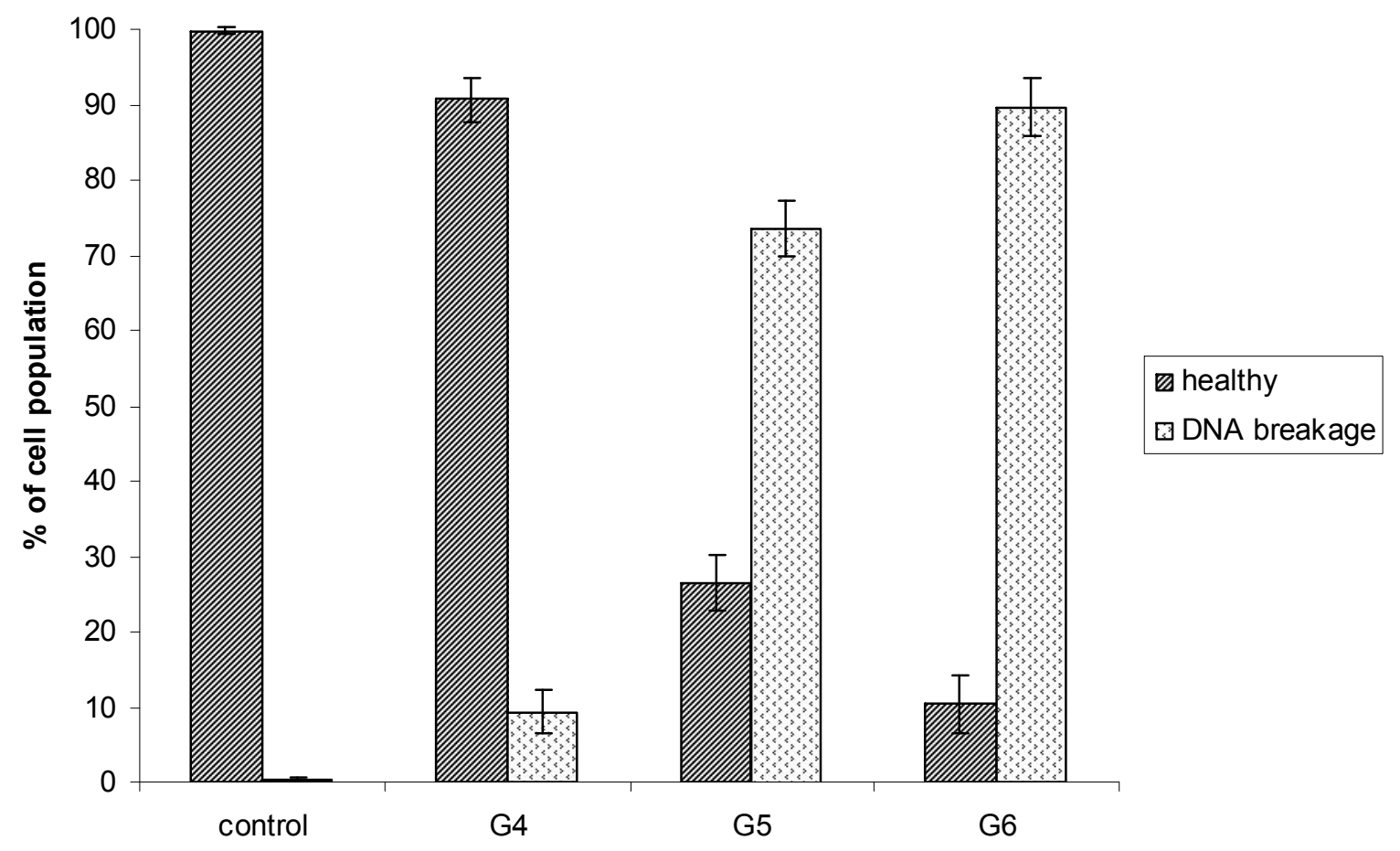


Figure 11.

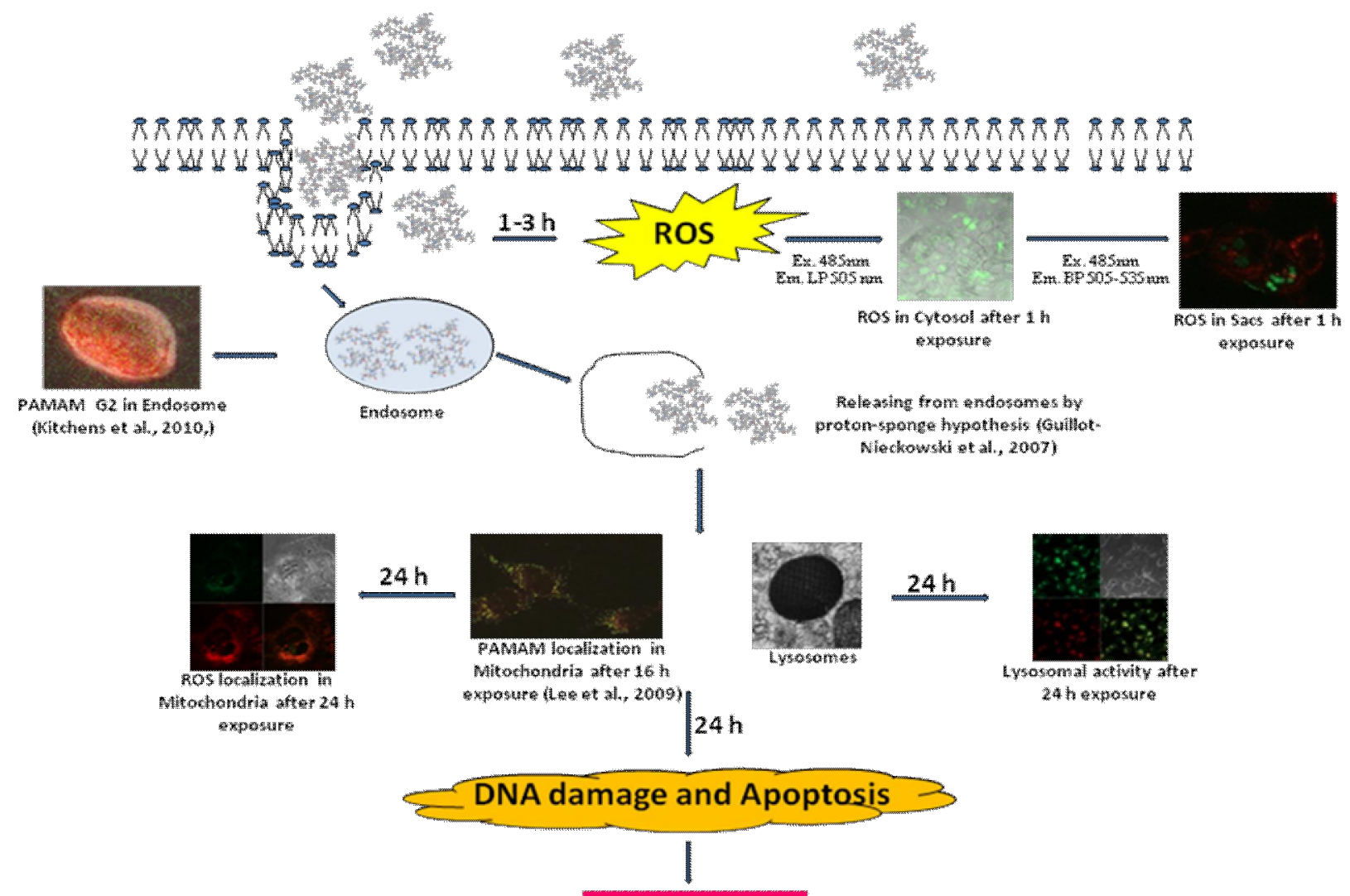

\section{Cell Death}

